Historic, Archive Document

Do not assume content reflects current scientific knowledge, policies, or practices. 


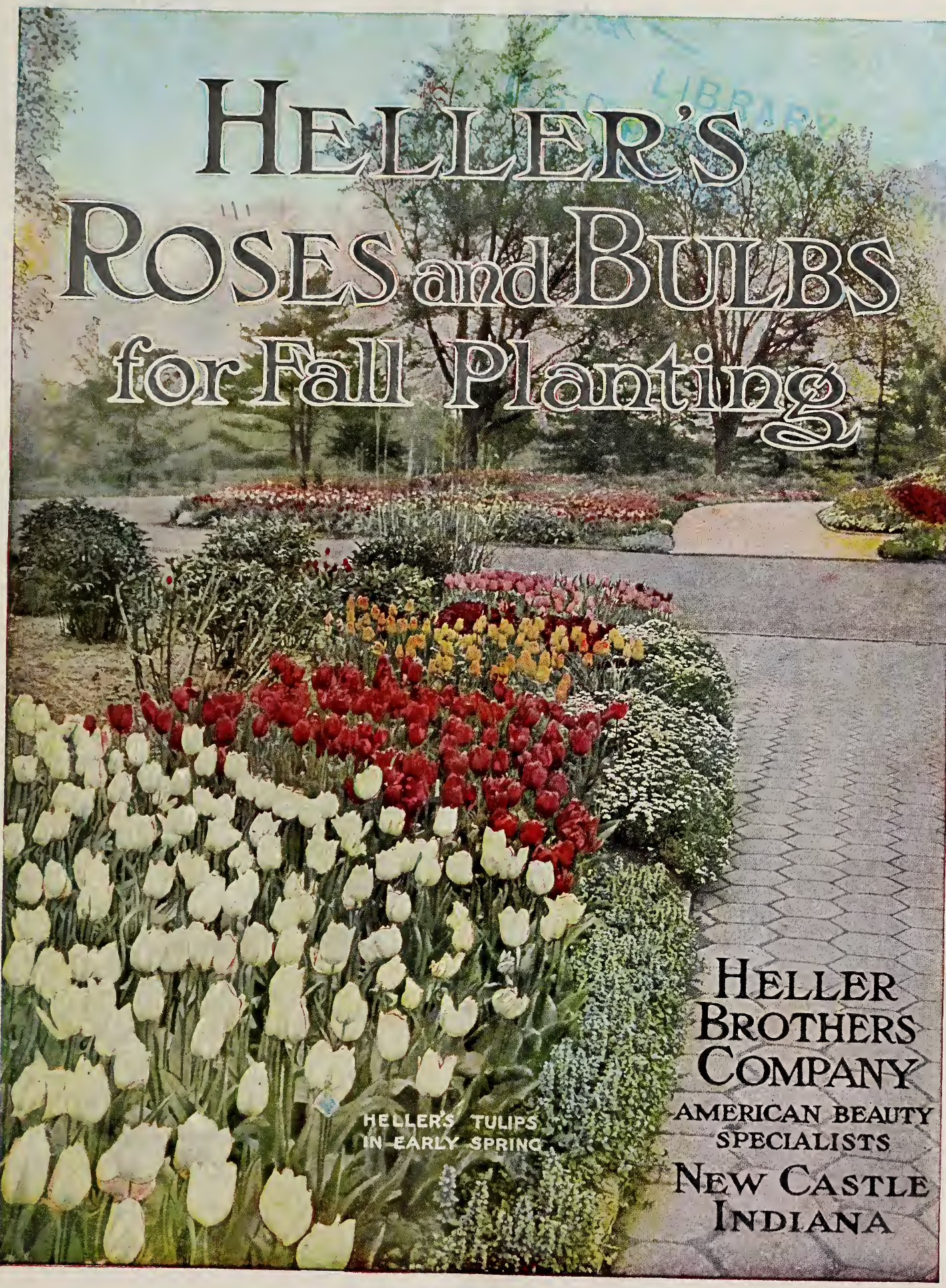




\section{Heller's Roses and Bulbs for Fall Planting}

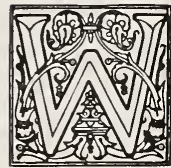

HEN Nature wakes from her long winter sleep, and the robins and blue birds brave the cold of our northern climate, those who love flowers look anxiously for the first signs of the beauty and glory which is to come to the garden.

That this may come, it is necessary to provide for it in the fall, and this little book's mission is to tell what to do this fall, that next spring and summer may fill the flower-lover's heart full of the joy of flowers.

First come the Hyacinths, Tulips, Daffodils and many other "sweet harbingers of spring," which can be had only by planting the bulbs in the fall. And then Roses. Many Roses do best when planted in the fall, and for this fall's planting we have prepared a splendid stock of plants which, if planted before early frosts, will be sure to grow and bloom next sumer in a most marvelous way.

Our great specialty for which we are world-famous is Roses on their own roots. As an indication of where our Roses go, and they are in truth world-famous, we shipped during the month of July live, growing plants to China, Tasmania, New Zealand, England, France, British West Indies and even to remote East India. In these days of quick delivery, we reach all parts of the United States without the slightest danger of the plants receiving a setback.

The same conditions and principles which have built up our enviable reputation for roses is applied to our bulbs and other things offered in this catalog. All our bulbs are grown for us by special growers in Holland, France, Japan, and other countries, practically under our own supervision. We offer only the first or largest size bulbs. We do not handle cheap, inferior stock which is dear at any price. We sell only the highest grade plants and bulbs, at prices that are actually lower than any others.

Almost the hour this book goes to press, the Congress of the United States passed a Parcels Post law. We are unable to state specifically what the advantages, if any, of this law are. It is sufficient for us to assure you, our patrons, that we will give you every advantage that this law affords in the way of prepaid delivery that is compatible witl a legitimate margin of profit for ourselves.

\section{TERMS OF SALE-HOW TO ORDER}

The prices and conditions in this book cancel all previous prices and terms.

Order Early. Orders will be shipped at once or whenever you direct. Please bear in mind that all the bulbs offered, Hyacinths, Tulips, Narcissi, Crocus, Lilies, etc., come from Holland, Germany, France and Japan. They should reach us ordinarily about September 1 . If there is a late season in any of these countries, then the bulbs do not reach us until later on in the month. Sometimes there is a delay in getting shipments through the custom houses. If you do not receive your order, you will know the reason for it. We will forward as soon as the bulbs reach us if you direct us to ship at once.

Send Cash with Order. We open accounts only when satisfactory bank reference is furnished. Goods will be shipped C. O. D. If desired, upon receipt of one-third the amount involved in advance.

To Avoid Loss, remit by postoffice or express money order, bank draft or registered letter. Sent in any of these ways money is at our risk. Do not send stamps unless it is absolutely more convenient, because danger of them coming stuck together is very great.

We Guarantee safe arrival of all orders sent by express in the United States. Should anything be injured in transit, notify us at once on receipt of goods, sending us a list of stock damaged, and we will replace them immediately. When the shipment arrives in good condition, our responsibility ceases. Goods sent other than by express are at the risk of the purchaser. All plants exported to foreign countries are at the purchaser's risk after delivery to the express company or the postoffice here. All goods with prices marked postpaid will be sent by mail with postage paid. All goods priced by express will be sent by express, purchaser to pay charges.

Complaints must be made promptly, within ten days after the arrival of the shipment, otherwise they will not be entertained.

We Give No Warranty, express or implied, as to description, quality, productiveness or any other matter of any seeds, bulbs or plants we send out, and we will not be in any way responsible for the crop. If the purchaser does not accept the goods on these terms, they are at once to be returned.

Canadian Customers. Our goods can be sent into Canada at any time except the dormant shrubs such are Hydrangeas, Snowballs, and these are admitted into the Dominion from March 15 th to May $15 \mathrm{th}$, and from October $7 \mathrm{th}$ to December $7 \mathrm{th}$ through St. John, N. B., St. Johns, Quebec, Niagara Falls, Winnipeg, Manitoba, where they will be fumigated. All our roses and other stock is admitted at any time. Canadian shipments are at purchaser's risk.

Foreign Orders. Twenty per cent should be added to all orders going outside of the United States and colonial possessions, to pay extra cost of packing and postage. Those countries where we have Parcels Post, goods can be sent by mail, also by express. Purchaser must give the name and address of someone in $\mathrm{N} \in \mathrm{w}$ York who will receive the goods, prepay charges and forward them. We pack lightly and safely and the charges, even to distant countries, are very reasonable.

By Way of Explanation to those of our friends whose orders during the past spring were delayed in the shipping, we ask them to remember the character of the weather conditions at that time. We have never known aything like it in twenty-five years. There was practically no spring at all, but instead a quick transition from winter into summer, bringing all our orders for delivery in so short a period that we were overwhelmed with the demand and simply could not meet it. It has always been our ambition to be prompt in making shipments. This year we worked night and day, every day in the week, including Sundays, and some of our friends were harsh and unjust in their criticisms. We can not change the weather and we can only do twenty-four hours work in a day. All our people stru, "gled marifully with the situation and everyone got their goods in good time. We hope that we shall never be called upon to go through another Spring season like that of 1912. 


\section{Heller's Superb Hyacinths}

Among the most magnificent of all spring-time flowers is the Hyacinth, with its handsome spike of bell-shaped flowers of the daintiest colors and exquisite perfume. Our list comprises the very best of all the finest Hyacinth bulbs from Holland, grown under our special, personal directions and imported direct from the most famous growers of the "land of dikes and ditches."

Do not Buy Second-size, Inferior Bulbs. Heller Hyacinths are grown by our special growers in Holland, extra-large size, the best to be had at any price.

Note.-The difference between Single and Double Hyacinths is solely in the individual flowers of the spikes. Otherwise, the habits of the two kinds are the same.

\section{How to Grow Heller's Hyacinths}

Indoors. Plant in pots or boxes, using ordinary garden soil, any time from September to February. Allow a small portion of the bulb to be exposed above the soil. Water thoroughly and put away in a dark, cool situation until signs of growth commence, then bring into the light and heat. To grow in water, use single Hyacinths preferably; place the bulbs in glasses and fill with clean water; leave them in a dark, cool cellar until the glass is well filled with roots, then bring to the light and heat.

Outdoors. Ordinary soil spaded to a depth of 12 inches, in a sunny location, is necessary. Plant the bulbs 5 inches deep and 6 or 7 inches apart. Set out any time from September until severe freezing weather, and give winter protection with dead leaves or garden litter.

\section{Single Hyacinths}

Extra-large bulbs, 17 cts. each; $\$ 1.75$ per doz; prepaid when sent by mail.

\section{RED, ROSE AND PINK}

Baron von Thuyll. Brilliant pink; large spike.

General Pelissier. Deep, rich scarlet. Early.

Gigantea. Blush-pink; grand large spike.

Incomparable. Brilliant scarlet.

Marie Comelia. Bright lively pink. Earliest.

Reine des Jacinthes. Bright scarlet; very fine.

\section{D.IRK AND LIGHT BLUE}

Captain Boynton. Sky-blue; very large.

Chas Dickens. Porcelain-blue; very fine. King of the Blues. Fine dark blue.

Menelik. Almost black; extra fine.

Perle Brilliant. Light blue; very large.

WHITE AND BLUSH

Blancheur a Merveille. Pure white; large.

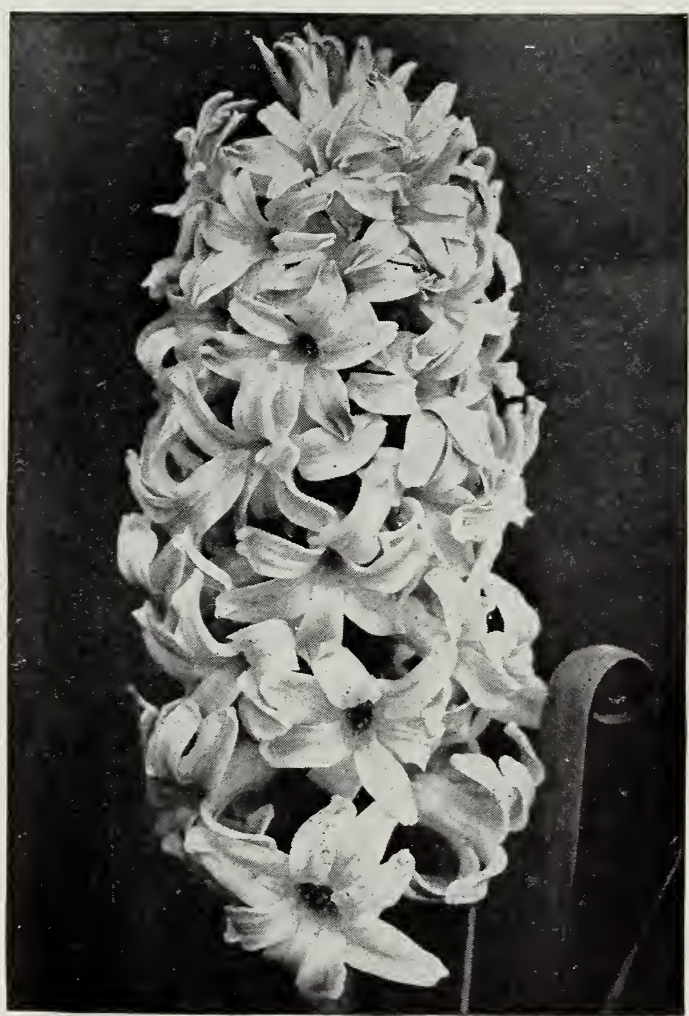

The Way our Hyacinths Bloom

Grand Blanche. Blush-white; extra large. La Grandesse. Pure, shining white.

\section{YELLOW}

King of the Yellows. Golden yellow; large.

SPECIAL OFFER:-We will send prepaid a complete set of the 15 named Single Hyacinths, extra fine, large bulbs, sure to bloom, for $\$ 2.00$ prepaid, when sent by mail. 


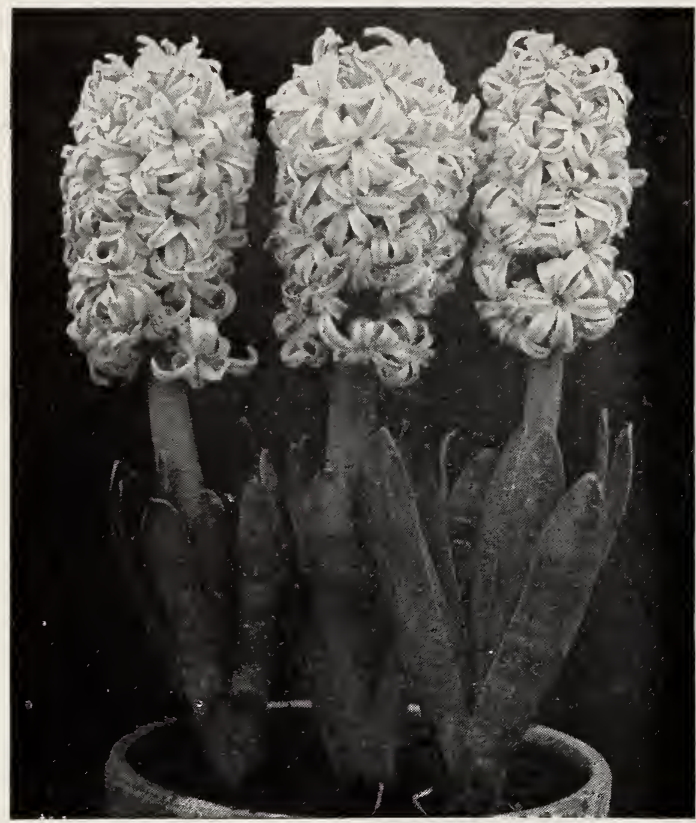

Heller's Hyacinths Blooming in the House

\section{Double Hyacinths}

Extra-large bulbs 17 cts. each; \$1.75 per doz., prepaid when sent by mail.

\section{RED, ROSE AND PINK}

Bouquet Royal. Rosy salmon; fine.

Bouquet Tendre. Dark red; large truss.

Lord Wellington. Bright pink. Early.

President Roosevelt. Deep pink; magnificent.

Princess Royal. Darlk red; deep centers.

\section{WHITE AND BLUSH}

Isabella. Blush-white; large.

La Tour d'Auvergne. Blush-white; extra fine.

Non I'lus Ultra. Snow-white; immense size.

\section{DARK AND LIGHT BLUE}

Blocksberg. Light blue; extra fine.

Garrick. Lilac-blue; fine spike.

Lold Raglan. Light blue, with dark center.

Othello. Blue-black; fine spike.

Van Speyk. Porcelain-blue; extra large.

\section{YELLOW}

Goethe. Bright yellow; very large.

Victoria. Brilliant yellow; extra fine.

SPECIAL OFFER: Collection of one each of the 15 named varieties of Double Hyacinths, correctly labeled. \$2. prepaid when sent by mail.

\section{Single Hyacinths}

\section{Separate Colors}

For those who desire to form Hyacinth beds without regard to the names of the varieties, we will make up special collections of bulbs according to color only. They are all large, healthy bulbs and will be sure to produce flowers freely next spring.

Doz.

100

Pure white and Blush....\$0.75

$\$ 6.00$

Red and Rose .......... . .75

6.00

Blue and Purple Shades. . .75 6.00

Yellow Shades ...........75 6.00

All Colors Mixed ........ .75 6.00

\section{Double Hyacinths, Separate Colors}

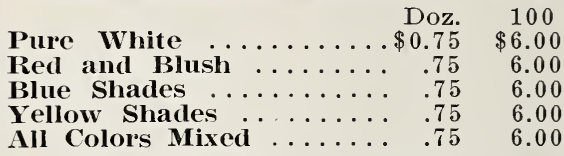

Orders for 6 of a kind filled at dozen rate.

At above prices shipment will be made by express, purchaser paying charges; if by mail, add 1c per bulb.

\section{Grape Hyacinths}

Entirely hardy and will increase very rapidly in the open ground. For winter blooming, plant a few bulbs in a 5 -inch pot and treat the same as the large Hyacinths.

Improved Blue. Sky-blue bells, tipped white. 3 for $5 \mathrm{c}$; $15 \mathrm{c}$ per doz., $75 \mathrm{c}$ per $100 ; \$ 6.00$ per 1,000 .

Snow-White. A very scarce sort. 3 for $10 \mathrm{c}$; $20 \mathrm{c}$ per doz.; $\$ 1$ per $100 ; \$ 8$ per 1,000 .

SPECIAL OFFER: 6 Improved Blue and 3 Snow-White Grape Hyacinths, 9 in all, for 15 ets.

The only way you can have your garden full of the glory of early spring is to prepare for it in the fall by planting our bulbs and other fall-planting specialties. As the Roses of New Castle have become worldfamous for their strength, vigor and beauty, the bulbs, roots and plants in this little book will keep up their enviable reputation. When goods are sent by mail we pay the postage, but when sent by Express the purchaser pays transportation charges unless 20 per cent is remitted with order to prepay express charges.

\section{Indianapolis, Ind., July 15, 1912.} Heller Brothers Co., Newcastle, Ind.

Gentlemen:-Although somewhat late in acknowledging receipt of your beautiful roses, I beg to report that we plucked the first roses yesterday, and they are beautiful and all doing fine. We have lost no plants, and I thank you again for the gift, which is appreciated.

Yours very truly.

Albert Lieber. 


\section{Heller's Tulips}

Culture of Tulips is the same as of Hyacinths except that bulbs should be planted 5 in. deep. Figure preceding the name shows height to which each variety grows.

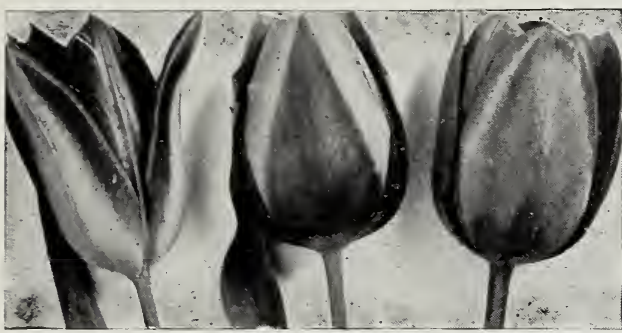

Rose Queen. Kaiserkroon. Scarlet Pottebakker

\section{Single Early Tulips}

Extra-large bulbs, 5c each; 50c per doz.; \$3 per 100; postage or express prepaid.

7 Arms of Leyden. White and red.

7 Artus. Brilliant red; extra fine.

8 Chrysolora. Golden yellow; large.

9 Duchesse de Parma. Red; yellow stripe.

8 Elenore. Violet; white edge.

8 Joost van Vondel. Silvery white; finest.

9 Keiserkroon. Red and gold; brilliant.

8 King of the Yellows. Golden yellow.

9 Moliere. Violet; extra large and fine.

7 Nelly. Pure white; very large.

8 White Pottebakker. The finest white.

8 Scarlet Pottebakker. Shining scarlet.

8 Yellow Pottebakker. Brilliant yellow.

8 Prosperpine. Carmine-rose; extra fine.

8 Rose Queen. Deep pink and white. New.

8 Vermilion Brilliant. Dazzling scarlet.

Magnificent mixture of Single Early Tulips.

The choicest named kinds, in all colors; will make a gorgeous mixed bed. Fine large plump bulbs, sure to bloom, 30c per doz.; \$1.75 per 100; $\$ 15$ per 1,000 ; postage prepaid.

\section{Single Late Tulips}

Fine for bedding and cutting. The stems average 2 feet in height.

Extra-large bulbs, 5c each; 50c per doz.; \$3 per 100 ; postage or express prepaid.

Isabella. Rose-pink, shaded white.

Bouton d'Or. Brilliant golden yellow. Small.

Konigskroon. A late Kaiserkroon.

La Nigrette. Almost black.

La Candeur. Pure white, changing to rose.

Picotee, or Maiden's Blush. White, with pink edges. Pointed petals.

SPECIIL OFFER: Mixed Single Late

Tulips, all color's, not named, fine, extra-

large, healthy bulbs for bedding or natura-

lizing, 30c per doz.; 50 for $\$ 1 ; \$ 1.75$ per 100 ; $\$ 15$ per 1,000, postage prepaid.

\section{Double Early Tulips}

Fine specimen bulbs, 5c each; $50 \mathrm{c}$ per doz.; \$3 per 100, postage or express prepaid.

7 Alba Maxima. Pure white; large.

9 Helianthus. Gold and scarlet; extra fine.
6 La Candeur. Glistening-white; fine bedder.

6 Murillo. Light pink; good forcer.

8 Purple Crown. Dark maroon.

7 Rex Rubrorum. Bright scarlet.

5 Rose Blanche. Pure white; extra fine.

6 Rose d'Amour. Delicate pink.

7 Salvator Rosa. White and rose.

7 Titian. Scarlet, edged with gold.

Special Offer of Mixed Double Early Tulips

a superfine mixture of the choicest named varieties, for bedding purposes, $30 \mathrm{cts}$. per doz.; 50 for $\$ 1 ; \$ 1.75$ per $100 ; \$ 15$ per 1,000 postage prepaid.

\section{Double Late Tulips}

Extra-heavy bulbs, 5c each; 50c per doz.;

$\$ 3$ per 100; postage or express prepaid.

Blue Flag. Violet-blue; extra fine.

Count Leicester. Yellow and orange.

Gloria Mundi. Brown, crimson and yellow.

La Belle Alliance. Blue and white.

Mariage de ma Fille. White, striped carmine.

Yellow Rose. Brilliant golden yellow.

SPECIAL OFFER: Mixed Double Late Tulips, all colors, for bedding, 30 cts. per doz.; 50 for $\$ 1 ; \$ 1.75$ per $100 ; \$ 15$ per 1,$000 ;$ postage prepaid.

\section{Darwin Tulips}

Extra-large bulbs, 10c each; \$1 per doz.; \$8 per 100 ; postage prepaid.

Baronne de la Tonnaye. Rose-pink.

Europe. Vivid scarlet-carmine.

Glow. Brilliant vermilion.

Gretchen. Blush-rose.

The Sultan. Maroon-black; magnificent.

SPECIAL OFFER: A splendid mixture of Darwin Tulips, all high-class bulbs, 80 cts. per doz.; $\$ 6.00$ per 100 , postpaid.

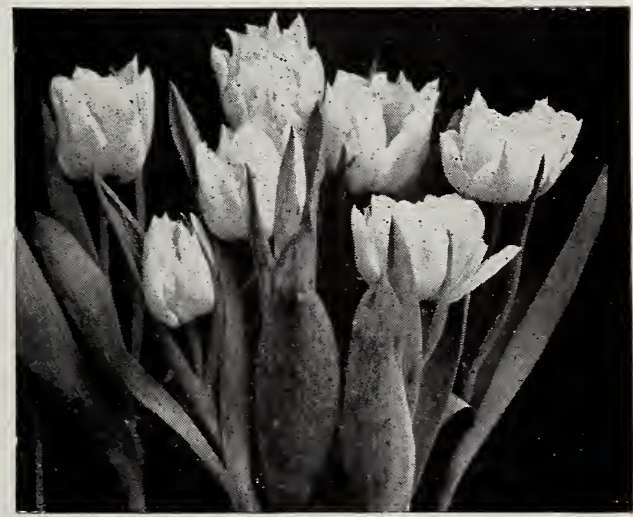

Double Early Tulips, Rose Blanche 


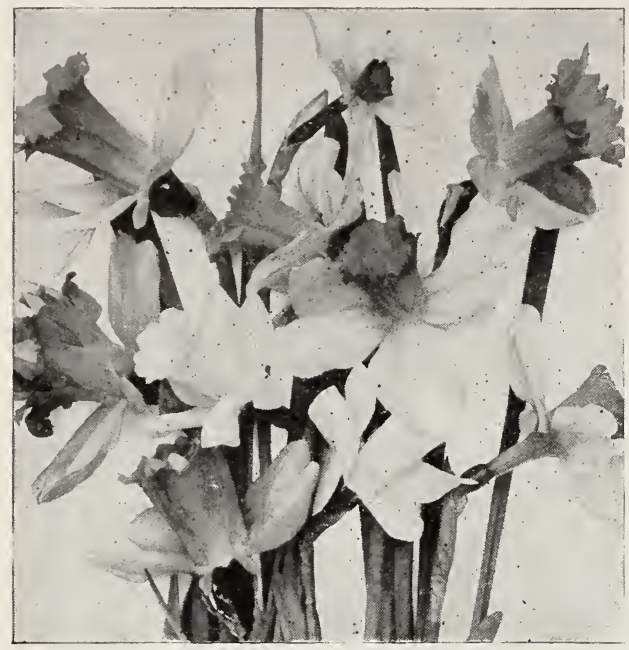

Single and Double Narcissi

\section{Parrot Tulips}

The most showy of all Tulips, with curiously fringed petals and bewildering colors. Plant shallow in light soil in the sun. Fine, large, healthy bulbs, 5c each; $75 \mathrm{c}$ per doz.; \$3 per 100, postage prepaid.

Admiral Constantinople. Fine red.
Cafe Brun. Brown and yellow striped.

Cafe Pourpre. Orange, feathered with scarlet.

Cramoisic Brilliant. Brilliant scarlet.

Lutea Major. Yellow; very fine.

Markgraaf von Baden. Orange, striped scarlet.

Perfecta. Yellow and scarlet.

SPECIAL OFFER: All color's mixed, splendid bulbs sure to bloom, 30c per doz.; 50 for $\$ 1 ; \$ 1.75$ per 100 , postpaid; $\$ 15$ per 1,000 , by express.

\section{Gesneriana Tulips}

A most effective class of late-flowering single Tulips in brilliant colors and handsome shapes, growing on stems 2 to 3 feet high. Splendid for cutting.

Splendid large bulbs, 5c each; 50c per doz.; \$3 per 100; except where noted, prepaid.

Crimson Gesneriana. Gorgeous, dazzling crimson, with center of deep blue.

Yellow Gesneriana. Brilliant yellow, with orange edges.

Viridiflora. Green, edged with yellow. Very large, unique and beautiful.

Gregi (The Royal Tulip). The most magnificent of all Tulips. Intense scarlet with black center and yellow anthers. Foliage is spotted with maroon. Always scarce, but we had a special lot of bulbs grown under contract and can supply them in limited quantity. 15 cts. each, $\$ 1.50$ per doz.; $\$ 10.00$ per 100 , postpaid.

\section{Narcissi, Daffodils and Jonquils}

Narcissi should be treated the same as Hyacinths. Can be naturalized in any garden where they will continue to thrive and bloom for years. Prices are postpaid when mailed.

\section{Single Narcissi}

Ard Righ (Irish King). Large, beautiful golden yellow. 10c each; $\$ 1$ per doz.; $\$ 8$ per 100 .

Emperor. Trumpet large, rich yellow, with deep primrose petals, $3 \frac{1}{2}$ inches across. 7c each; 75c per doz.; $\$ 6$ per 100 .

Bicolor Empress. Golden yellow trumpet, surrounded by white perianth. 7c each; $75 \mathrm{c}$ per doz.; $\$ 6.00$ per 100 .

Maximus, or Vase of Beate: Gold. Early. Immense flowers of deepest, richest yellow. $7 \mathrm{c}$ each; 75c per doz.; $\$ 6$ per 100 .

Glory of Leiden. Long trumpet of rich yellow. $20 \mathrm{c}$ each; $\$ 2$ per doz.; $\$ 15$ per 100 .

Pseudo, or Lent Lily. Light yellow cup with sulphur-white perianth petals. $5 \mathrm{c}$ each; 50c per doz.; $\$ 3.50$ per 100 .

Trumpet Major. Golden yellow. Early. 5c each; 50c per doz.; $\$ 3.50$ per 100 .

Pallidus Praccox. Sulphur-white perianth and trumpet. One of the earliest. $6 \mathrm{c}$ each; 60c per doz.; $\$ 4.50$ per 100 .

Stella. Large white perianth petals, with golden yellow cup, star-shaped. $3 \mathrm{c}$ each; $30 \mathrm{c}$ per doz.; $\$ 1.50$ per 100 .
Sir Watkin. One of the biggest and best. Rich sulphur-yellow, orange-tinged trumpet. 7c each; 75c per doz.; $\$ 6.00$ per 100 .

Leedsi. Pure white petals, lemon cup, passing to white. $3 \mathrm{c}$ each; $30 \mathrm{c}$ per doz.; $\$ 2$ per 100 .

\section{Double Narcissi}

Double Von Sion. The grand old double yellow Daffodil. It can remain undisturbed for years. One of the very best for house culture. Epecially selected, double-nosed bulbs, far superior to the average bulbs. $5 \mathrm{c}$ each; $50 \mathrm{c}$ per doz.; $\$ 4.00$ per 100 .

Orange Phocnix (Eggs and Bacon). Very handsome, double, white flowers; outside petals white; center orange and white. $5 \mathrm{c}$ each; 50c per doz.; $\$ 3.50$ per 100 .

Superfine Mixed. Superb mixture of all sorts. Double and Single and all colors. $5 \mathrm{c}$ each; 50c per doz.; $\$ 3.50$ per $100 ; \$ 25$ per 1,000 .

SPECIAL OFFER: Set of 13 named Narcissi, postpaid, $\$ 1 ; 3$ of each, 39 in all, $\$ 2.50 ;$ postpaid. 


\section{Polyanthus Narcissi}

Double Roman. Perfectly double. Clear white, with smaller inner petals of pure yellow; an early and profuse bloomer; delicious fragrance. $3 \mathrm{c}$ each; $30 \mathrm{c}$ per doz.; $\$ 2$ per 100.

Improved Paper White. Snow-white flowers of large size and good substance, in immense trusses. Should never be planted outdoors. $5 \mathrm{c}$ each; $50 \mathrm{c}$ per doz.; $\$ 3$ per 100 .

True White Pearl. White flowers, with primrose cups. $10 \mathrm{c}$ each; $\$ 1$ per doz.; $\$ 8$ per 100 .

Gloriosa. Perianth white, cup glowing, orange-yellow. 7c each; 75c per doz.; $\$ 6.00$ per 100 .

Grand Primo. White, with citron cup. Early. 7c each; 75c per doz.; $\$ 6$ per 100.

Grand Soleil d'Or. Yellow, with reddish orange cup. $7 \mathrm{c}$ each; $75 \mathrm{c}$ per doz; $\$ 6.00$ per 100 .

Mixed Polyanthus Narcissi. $50 \mathrm{c}$ per doz.; $\$ 2.75$ per 100 .

SPECIAL OFFER: Set of 6 named Polyanthus Narcissi as above, 50c; 6 of each, 36 in all, $\$ 2.50$, postpaid.

\section{Narcissus Corbularia}

Of all the winter-blooming bulbs in the house, there is none easier to succeed with, nor any which gives a greater reward. The bell-shaped flowers are clear, golden yellow in color, with exquisite odor, very odd in shape. Desirable for open ground. $8 \mathrm{c}$ each, $80 \mathrm{c}$ per doz.; $\$ 7$ per 100 , postpaid.

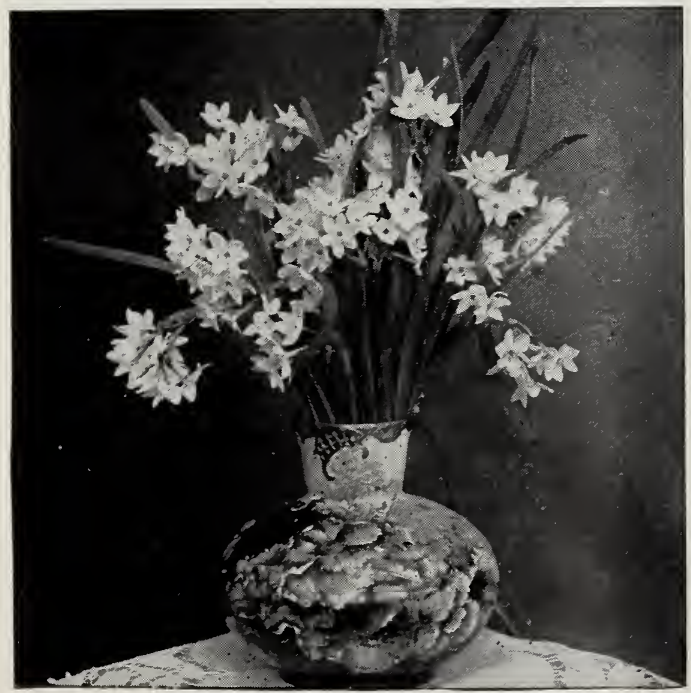

Improved Paper White Narcissus

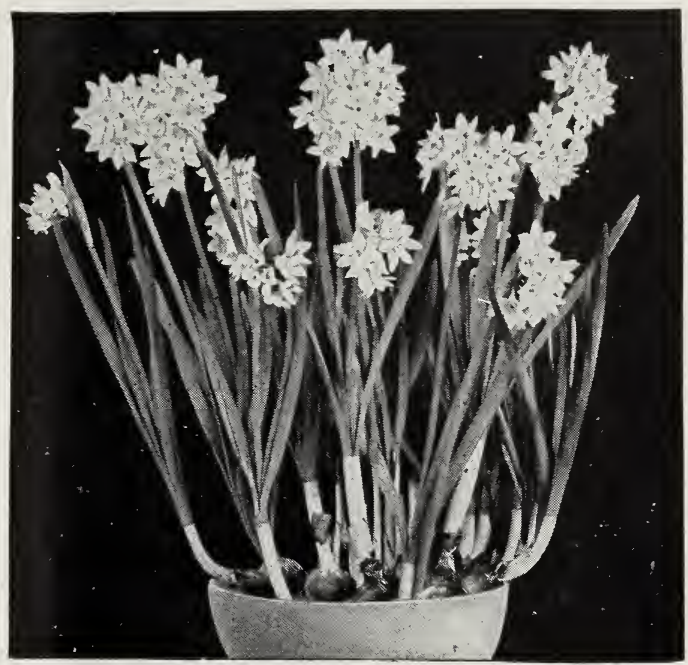

A Bowlful of Giant White Narcissi makes a handsome adornment to the home.

\section{Famous Giant White Narcissi}

A most unique early-flowering novelty, blooming in six weeks after planting. Grows with absolute certainty and produces in lovely clusters immense numbers of pure white flowers.

Grow it in water. Use at least six bulbs to a good-sized bowl. Place sand or pebbles in the bottom, firmly imbedding the bulbs, and keep well covered with water. Price, postpaid, by mail, 2 for $10 \mathrm{c} ; 6$ for $25 \mathrm{c}$; $40 \mathrm{c}$ per doz., postpaid.

\section{Jonquils}

Double. Extra fine; deep yellow. 4c each; 40c per doz.; $\$ 2.50$ per 100 .

Single. Rich yellow; very fragrant. 4c each; 40c per doz.; $\$ 2.50$ per 100 .

Campernelle Mixed. Large yellow flowers. 3c per doz.; $\$ 2$ per 100 .

\section{Narcissus Poeticus}

Poeticus. Pure white, with orange cup, edged with crimson. $3 \mathrm{c}$ each; $30 \mathrm{c}$ per doz.; $\$ 1.50$ per 100 .

Poeticus flore pleno. Double, white, sweet-scented flowers. $3 \mathrm{c}$ each; $30 \mathrm{c}$ per doz.; $\$ 1.50$ per 100 .

Poeticus ornatus. Very large, pure white flowers, beautifully formed eye. $5 \mathrm{c}$ each; 50c per doz.; $\$ 3$ per 100 .

All prices on this page include postpage, which we pay. 


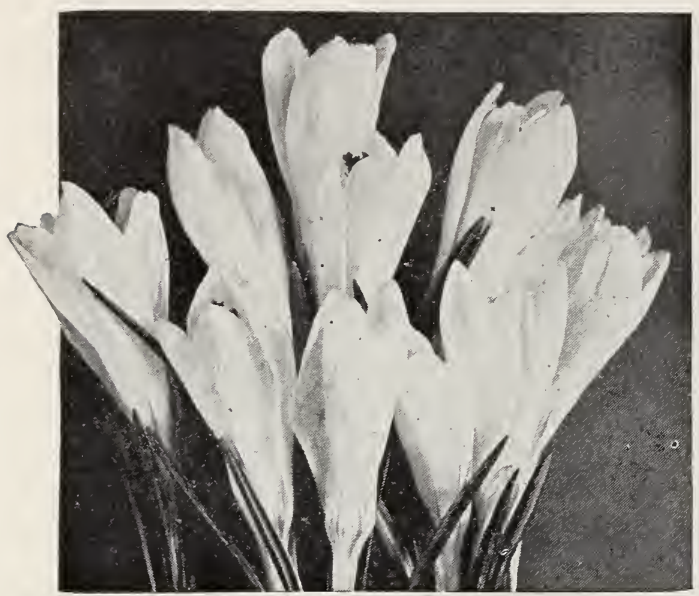

Monster Yellow Crocuses

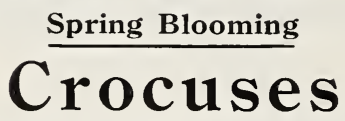

The best results with Crocus are obtained when they are given a rich, dry soil and sunny location. The bulbs should be planted about three inches deep; set singly or massed in beds. A favorite plan is to grow them in the grass on the lawn. Raise the sod with a spade or trowel to the depth of 3 inches, place the bulb beneath the sod and press back into place.

\section{Named Varieties}

15 cts. per doz.; $\$ 1$ per $100 ; \$ 9$ per 1,000 ; postage prepaid.

Albion. Fine striped; large and good.

Caroline Chisholm. The best white.

Lord Byron. Superb blue.

Sir Walter Scott. Very distinct; striped.

Queen Victoria. Splendid pure white.

Cloth of Gold. Golden orange, suffused with

dull brown, stigma orange-scarlet.

Cloth of Silver. Silver-white, striped lilac. Scotch. White, beautifully striped.

Versicolor. Varying from purple to white.

\section{The Monster Yellow Crocus}

Magnificent, desirable for open ground or pot culture. Bulbs very large and flower early; profusion of bloom is remarkable, fifteen to twenty-five large flowers being the usual number per bulb. By planting at intervals a succession of bloom can be had. 6 for 10 ets.; 15 ets. per doz.; $\$ 1$ per 100 , postpaid; $\$ 9$ per 1,000 by express.

\section{Finest Mixed Crocuses}

12 cts. per doz.; 75 cts. per 100, postpaid; $\$ 6$ per 1,000 , by express.

Mixed White. Different varieties.

Mixed Purple and Blue. Different varieties.

Mixed Striped. Different varieties.

Mixed Yellow. Different varieties.

All Colors Mixed. Different varieties.

\section{Heller's Freesias}

The most interesting of all winter-blooming bulbs growing well in ordinary soil and one of the best kinds for growing in the house. The color is pure white, lower petals touched with yellow. When cut, the flowers last two or three weeks in water and fill the house with most exquisite perfume. Plant them early-the earlier, the better. Order them as soon as you receive this book. Our bulbs are produced by our special growers, and we offer larger quality bulbs than those generally sold.

\section{Freesia refracta alba Strain}

The standard variety, easy to grow and certain to bloom in the window garden.

First-size monster bulbs. 3 years old. 7 cts. each, 10 cts. for $50 ; 25$ for $\$ 1 ; \$ 4$ per 100 , postpaid.

Second-size mammoth bulbs, about $1 / 2$ inch in diameter, 3 for 10 cts.; 30 cts. per doz.; $\$ 2$ per 100 ; postpaid.

Third-size, extra-large, selected bulbs, $12 \mathrm{c}$ per doz.; 50 for $50 \mathrm{c} ; 90 \mathrm{c}$ per 100 , prepaid.

\section{New Freesia, Purity}

A distinct and charming variety, having all the magnificence of the family in a superlative degree; a few bulbs will give a wonderful display. $7 \mathrm{c}$ each; $65 \mathrm{c}$ per doz., postpaid.

\section{Amomatheca Cruenta}

(Scarlet Freesia)

Similar in bulb, foliage and habit to the Freesia, but the flowers are brightest scarlet; the lower petals deeply marked. $5 \mathrm{c}$ each; 3 for $10 \mathrm{c} ; 25 \mathrm{c}$ per dozen, prepaid. (Delivered in November.)

\section{Oxalis}

A charming house plant with broad, clover-like foliage and dainty flowers in many colors.

Grand Duchess. In continuous bloom all winter. Rose-pink, White and Lavender. $5 \mathrm{c}$ each; $50 \mathrm{c}$ per doz.; $\$ 3.50$ per 100 .

Bermuda Buttercup. New, large-flowering; yellow. $5 \mathrm{c}$ ea.; $50 \mathrm{c}$ per doz.; $\$ 3.50$ per 100 .

\section{Fancy Leaved Caladiums}

One of the finest foliage plants, with splendid large leaves, beautifully spotted, margined and variegated with every imaginable color except blue. Supplied in bulbs only. Ready for delivery in December. Extra-large bulbs, $25 \mathrm{c}$ each; 3 for $60 \mathrm{c}$; 5 for $\$ 1.00$. 


\section{Heller's Handsomest of All Lilies}

The following limited list of hardy Lilies comprises those which do best by planting in the fall, but the earlier they are planted the better. Set them in good, fertile soil, 6 to 8 inches deep, each bulb surrounded by a half-inch of sand. Their glorious flowers of radiant beauty soon become a feature of the garden. They grow vigorously and survive from year to year.

Iuratum. Magnificent pure white flowers, exquisitely spotted with rose, and rayed and banded with yellow. Extra-selected, blooming bulbs, 20c each; 3 for $50 \mathrm{c} ; 6$ for $\$ 1$; enormous bulbs, 25 c each; 5 for $\$ 1$, prepaid.

Longiflorum, or Japan Easter Lily. Beautiful snow-white, fragrant Lily. $15 \mathrm{c}$ each; 4 for $50 \mathrm{c}$; 9 for $\$ 1$; extra-large bulbs, 20 c each; 6 for $\$ 1$; enormous bulbs, 25 c each; 5 for $\$ 1$, prepaid.

Candidum. The well-known Annunciation Lily, or St. Joseph's Lily, so plentifully grown in old gardens. $15 \mathrm{c}$ each; 4 for $50 \mathrm{c} ; 9$ for $\$ 1$.

Speciosum Album. Glistening white, very fragrant. $15 \mathrm{c}$ each; 4 for $50 \mathrm{c} ; 9$ for $\$ 1$.
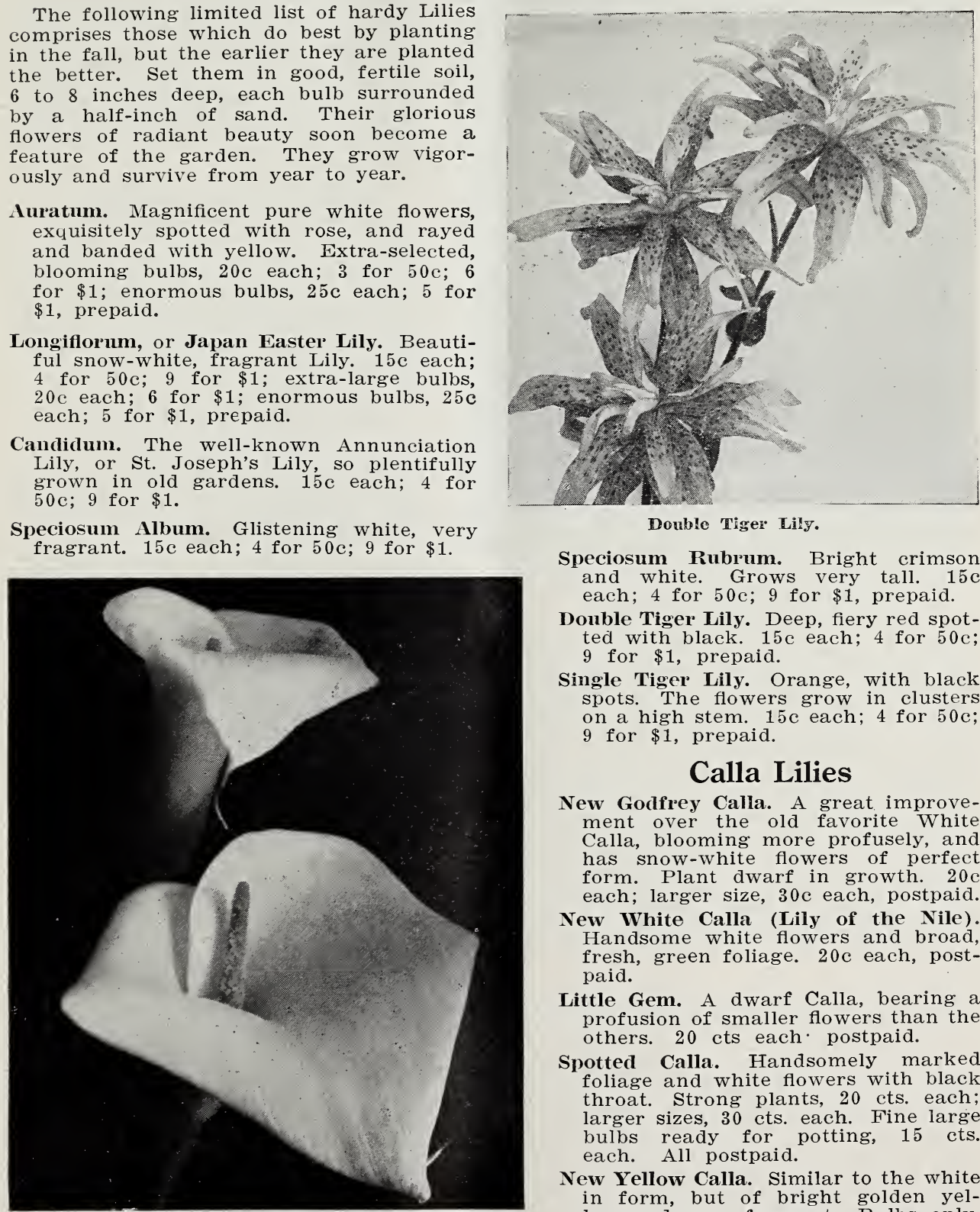

Double Tiger Lily.

Speciosum Rubrum. Bright crimson and white. Grows very tall. $15 \mathrm{c}$ each; 4 for $50 \mathrm{c}$; 9 for $\$ 1$, prepaid.

Double Tiger Lily. Deep, fiery red spotted with black. $15 \mathrm{c}$ each; 4 for $50 \mathrm{c}$; 9 for $\$ 1$, prepaid.

Single Tiger Lily. Orange, with black spots. The flowers grow in clusters on a high stem. $15 \mathrm{c}$ each; 4 for $50 \mathrm{c}$; 9 for $\$ 1$, prepaid.

\section{Calla Lilies}

New Godfrey Calla. A great improvement over the old favorite White Calla, blooming more profusely, and has snow-white flowers of perfect form. Plant dwarf in growth. $20 \mathrm{c}$ each; larger size, 30c each, postpaid.

New White Calla (Lily of the Nile). Handsome white flowers and broad, fresh, green foliage. $20 \mathrm{c}$ each, postpaid.

Little Gem. A dwarf Calla, bearing a profusion of smaller flowers than the others. 20 cts each ' postpaid.

Spotted Calla. Handsomely marked foliage and white flowers with black throat. Strong plants, 20 cts. each; larger sizes, 30 cts. each. Fine large bulbs ready for potting, 15 cts. each. All postpaid.

New Yellow Calla. Similar to the white in form, but of bright golden yellow and very fragrant. Bulbs only, 20 cts. each; 6 for $\$ 1$; postpaid. 


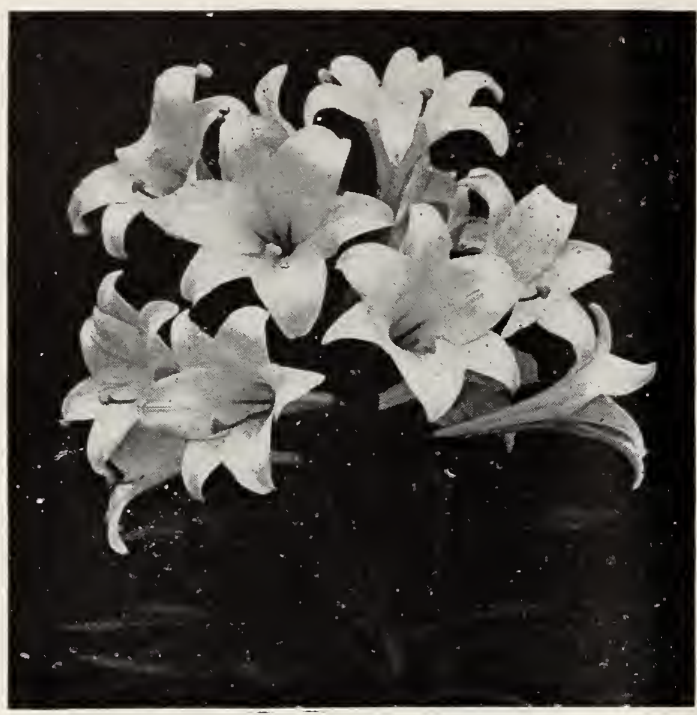

The Glorious Easter Lily

\section{Bermuda Easter Lily}

The Lily which has become indispensable for Easter decoration in home and church.

The genuine bulbs, imported direct from our Bermuda grower. The most popular of all flowers for Easter. Can be had in bloom at Easter-tide by planting the bulbs in pots 6 inches deep, with free drainage. Set the pots away in a warm place until roots are formed, and three months prior to Waster bring into light and heat, with plenty of moisture. Bermuda Lilies may be planted in the garden, where they will bloom in August. In the northern states they require protection. Large bulbs, popular size, producing 3 to 6 flowers, 15 cts. each; 4 for $50 \mathrm{c}$; prepaid. Extra-large bulbs, producing 8 to 12 flowers, $20 \mathrm{c}$ each; 6 for $\$ 1$, prepaid. Bulbs of enormous size, producing 12 to 15 flowers, $40 \mathrm{c}$ each; 3 for $\$ 1$, prepaid.

\section{Mexican Lily (Sprekelia Formosissima)}

This interesting Lily grows readily in soil, but the quickest method is to plant bulbs in sand, pebbles, gravel and water, like hyacinths, or Chinese sacred liles. Grown by this method, it blooms in two or three weeks. Not less than three bulbs should be planted to give best effect. The flowers are velvety dark scarlet. Large, blooming bulbs, $20 \mathrm{c}$ each; 3 for $50 \mathrm{c}$; 7 for $\$ 1$, postpaid. (Delivery in November).

\section{Lily-of-the-Valley}

Every one knows the beauty of these Lilies with their slender wands of dainty bells. For house culture, plant rather thickly in pots or boxes. Scatter some moss or other light material over the soil, water well and set away in a dark place for a few weeks. Strongflowering crowns, grown exclusively for us in Germany. 3 for $15 \mathrm{c}$; $50 \mathrm{c}$ per doz.; $\$ 3$ per 100 , postpaid.

\section{Chinese Sacred Lily}

The favorite method of culture is growing in water and gravel, where it can be depended upon to flower within twenty to thirty days after planting. Price, extra-large, solid bulbs, for immediate bloom, $15 \mathrm{c}$ each; 4 for $50 \mathrm{c}$; $\$ 1.50$ per doz.; postpaid. Mammoth bulbs, 20c each, postpaid.

\section{Giant Golden Sacred Lily}

Large, sweet, golden yellow flowers; hardy; thrive in any window garden. Blooms quickly and freely in soil, sand or pebbles and water. Beautiful and very fragrant. Large bulbs, 5c each; $50 \mathrm{c}$ per doz., postpaid.

SPECIAL OFFER: 3 Chinese Sacred Lilies and 3 Giant Golden Sacred Lilies for 50 cts.; 6 of each, 12 in all, for $\$ 1$, postpaid.

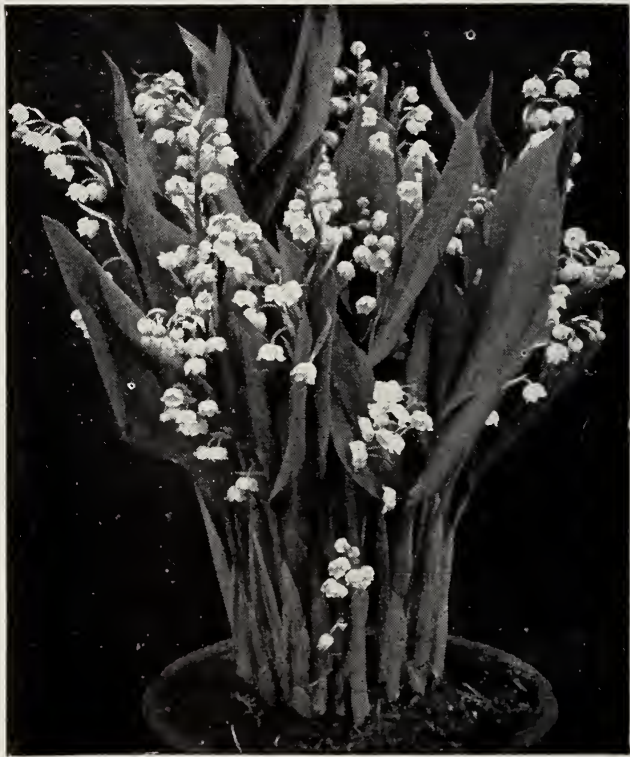

Lilies-of-the-Valley Make Fine Pot Plants 


\section{Giant Persian Cyclamen}

The most beautiful and decorative of all pot plants. The fairy-like rose, white and crimson flowers are carried on long stems and are delightfully perfumed. The foliage is broad, dark green, variegated with rose and silver. Immense bulbs grown especially for us in Europe. $20 \mathrm{c}$ each; 3 for $50 \mathrm{c}$; 6 for $\$ 1 ; \$ 2$ per doz.; or one bulb each of the three colors for $50 \mathrm{c}$. Mixed colors, 4 for $50 \mathrm{c}$; $\$ 1.25$ per doz., postpaid.

\section{Snowdrops (Galanthus)}

The first blossoms of spring. They are perfectly hardy and splendidly adapted for pot culture. Fine for planting all over the lawn.

Nivalis. Pure white and graceful. 3 for $5 \mathrm{c} ; 15 \mathrm{c}$ per doz.; $\$ 1$ per 100 , postpaid,

Elwesi (Giant Snowdrop). The largest and most beautiful of all Snowdrops. 2 for $5 \mathrm{c} ; 20 \mathrm{c}$ per doz.; $\$ 1.25$ per 100 , postpaid.

\section{Glory-of-the-Snow}

\section{(Chionodoxa)}

Lucilliae. Spikes of beautiful azureblue, with pure white center. 2 for 5 c; 20 c per doz.; $\$ 1.25$ per 100 , postpaid.

Gigantea. Larger flowers of a beautiful light blue, with white center. 2 for $5 \mathrm{c} ; 25 \mathrm{c}$ per doz.; $\$ 1.50$ per 100 , postpaid.

\section{Feathered Hyacinth}

Dainty plumes of feathery flowers borne on graceful stems. A delightful shade of blue tinged with red. For outdoors or in the house. 4 for $10 \mathrm{c} ; 25 \mathrm{c}$ per doz., prepaid.

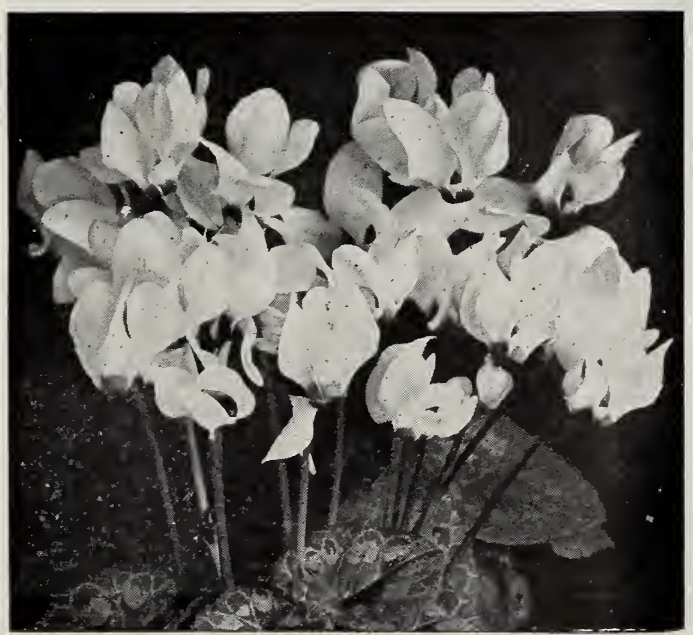

The Charm of the Cyclamen Flowers

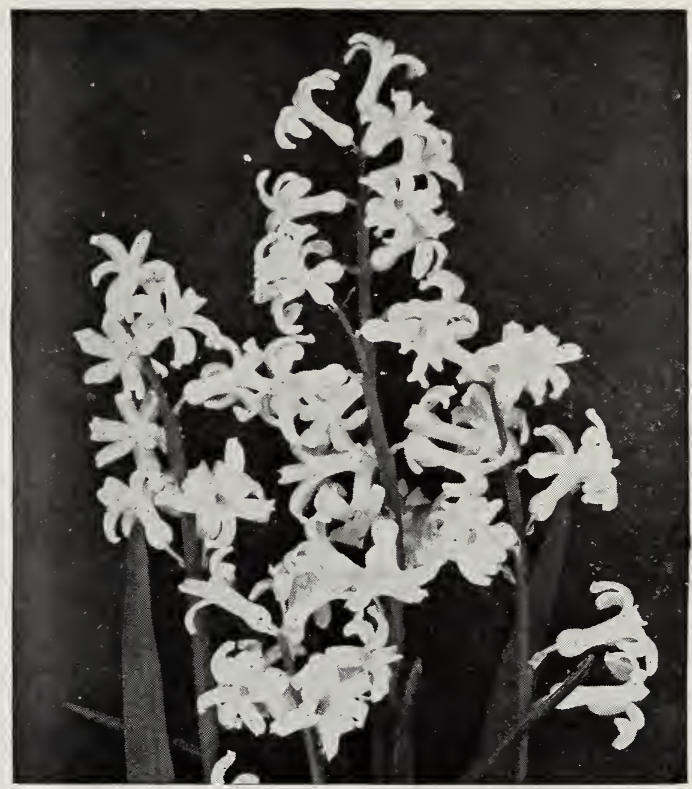

The Dainty Bells of the Roman Hyacinths

\section{Tufted Hyacinths}

Handsome racemes of deep blue, tassellike flowers. Will thrive in the open or inside the house. 4 for $10 \mathrm{c} ; 25 \mathrm{c}$ per doz.; prepaid.

\section{Roman Hyacinths}

May be had in bloom as early as Christmas. The graceful flowers embrace the most delicate colors and are very sweet-scented. May be grown in pots or glasses.

Prices for each of the following varieties; First size bulbs, sure to bloom, 5 cts. each; 6 for 25 cts; 50 cts. per doz.; \$3.75 per 100; prepaid.

Single White. Elegant bells; waxy white color.

Single Blue. Fine for contrasts.

Double Dark Pink. Grand spikes; large bells.

SPECIAL OFFER: Set of three named Roman Hyacinths, described above, for 12 cts.: 4 of each, 12 in all, for 40 cts., prepaid.

Edwards, Indiana, May 2, 1912. Heller Brothers:

Gentlemen:- My order of roses arrived yesterday in good condition. Thanking you, Mrs. Fred A. Walker. 


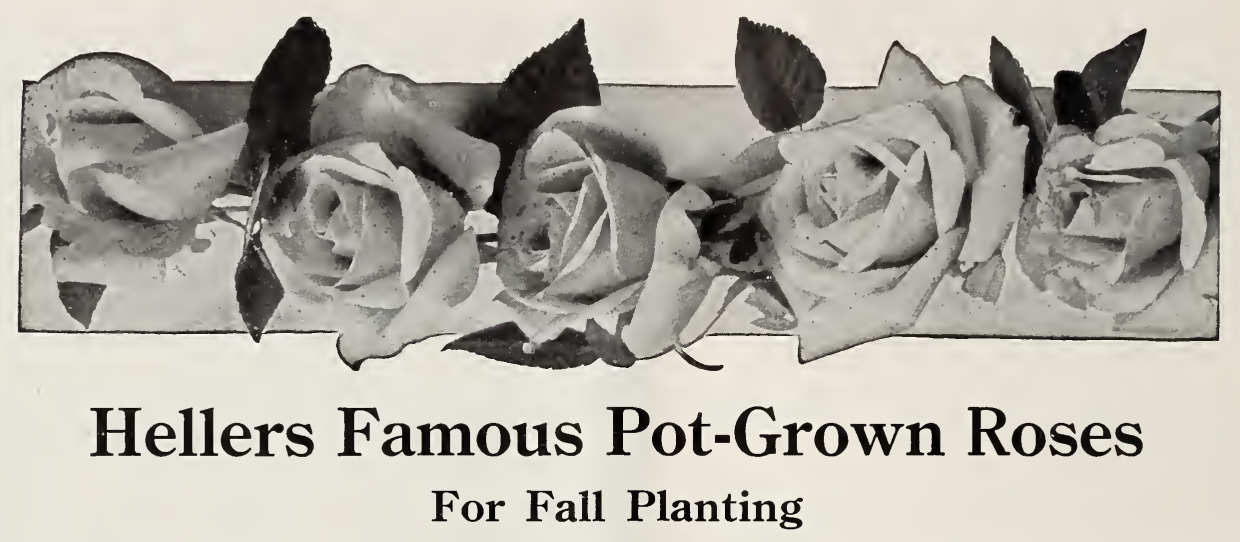

For years we have strongly urged our friends to plant Roses in the Fall-the earlier the better. Nursery grown Roses are not suitable for this purpose. The plants must be specially prepared for fall planting. As far as we know we are the only growers who make a specialty of Rose plants for both indoor or outdoor cultivation. You gain almost a year by planting now. Our plants as grown in pots or crocks and may be planted now-anytime until the earth is frozen.

We have especially prepared a type of plant for this purpose-larger and higher grade than ordinarily, a plant grown in pots $3,3 \frac{1}{2}, 4$ and 5 inches in diameter-a plant that is strongly rooted, in perfect health - in short, the best Rose that can be growna typical Heller Rose-well-bred and high class.

The astonishing resuits produced by these plants has spurred us on to even a greater advance in their propagation this year. While this new class of plants is considerably higher in price than ordinary Rose plant, Rose-growers are accustomed to buying they are so infinitely superior as effectually to dispose of any comparison either in quality or price. They are the cheapest, not in price, but compared by results-and results, after all, are what we are willing gladly to pay for.

A structure built on a cheap foundation is short-lived-a Rose business which is built on cheap prices, which means cheap goods, has but a short race to run. The day of the weak "little slips" sold as "Rose plants" has gone, and a new era has dawned in the Rose business. Dealers who are not equipped for the changing of the ways, and who fear the leap from this class of stock into high-class goods, cannot hope to figure as a factor in the Rose-growing world.

We are the leading Rose-growers of America. Roses on their own roots is our specialty. We carry an immense stock. There has been a large, unsatisfied demand from planters, both North and South, for the best varieties of Roses suitable for autumn planting outdoors. We propose to satisfy that demand. The important point is plant early. Protect with evergreen boughs, leaves and litter and then these varieties will invariably go through the winter safely. All Roses offered in this book are pot-grown and especially suited for winter blooming indoors, and have been specially selected with that purpose in view.

Their cultivation is extremely simple. Indoors, plant in pots or boxes, water freely, shade them from the direct rays of the sun with newspapers for a few days, then give them as much light and sunshine as possible. Outdoors, give them good, fertile soil, shade from the sun for a few days, and, after the first frost, protect with dead leaves, straw or coarse manure.

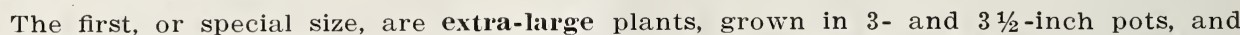
at prices named will be sent by mail postpaid, or by express, leaving a portion of the soil around the roots, prepaid, if 20 per cent is added to the total amount of the order. The two-year-old plants are from $4 \frac{1 / 2}{2}$ - and 5 -inch pots. Two-year-old plants by express. If you wish us to prepay the express charges, add 20 per cent to your order, otherwise goods will be shipped charges collect. Heller Roses have made the town of New Castle famous-none better and few as good. We invite a test of the truth of this claim. 


\section{AMERICAN BEAUTY}

Massive in Size, Gorgeous in Color

Exquisite in Perfume

\section{Our American Beauty Rose is Famous the World Over}

We are the leading growers of American Beauty Roses in this country and may fairly claim to have been largely responsible for its wonderful popularity. It has been proved hardy in practically all sections of the country, but in extremely cold climate, it should have careful winter protection. See instructions for fall planting elsewhere.

It is important to secure the true stock; beware of low-priced plants that are not really Imerican Beauties.

\section{Buy Heller's \\ American Beauties}

Our stock is known as the best in the World. Especially prepared for Autumn planting

The color is rich, glowing crimson, charmingly shaded and veined and, as the flowers expand, their beauty seems to be enhanced rather than diminished. The fragrance is nothing short of exquisite; in short this glorious Rose seems to have been endowed with all the charms and grace of the entire Rose family.

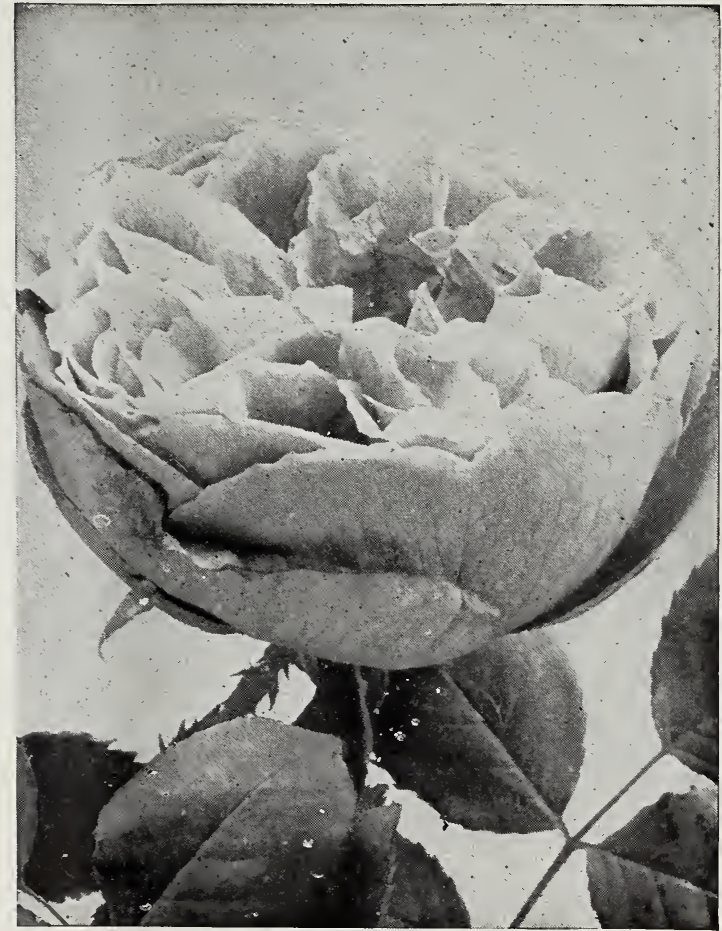

An American Beauty Rose as grown on our plants.

No special care is required to succed with our American Beauty Roses. Our stock is clean, strong, healthy and vigorous in every particular. And what is more important, it is true to name and on its own roots.

This great Rose should be in the flower-garden of every American home. The name, its magnificent beauty, exquisite fragrance and wonderful merit must apeal to the patriotic instincts of every true American.

Strong pot-plants, special size, 25c each, postpaid; extra-size, 2-yr.-old plants, 50c each; \$5 per dozen; 3-yr-old specimen plants (limited quantity) $75 c$ each; $\$ 8$ per dozen, by Express.

Baltimore, Md., July 6, 1912.

Mr. P. J. Lynch, Mgr., Heller Bros. Co.

Dear Sir:-The plants were received yesterday in excellent condition and taking them as a whole they are a very fine lot.

Thanking you for your prompt attention to my last letter and wishing you your share of success, I am, Yours very truly,
Bunker Hill, West Va., May 10, 1912. Heller Brothers Co., Newcastle, Ind.

Gentlemen:-The box of plants arrived safely by yesterday's mail. I sent a letter yesterday to know about them. Suppose. I was over anxious but did not want them to go astray. They looked very fresh and nice. Very truly, Mrs. J. W. Bronson. 


\section{The Lovely Killarney Roses}

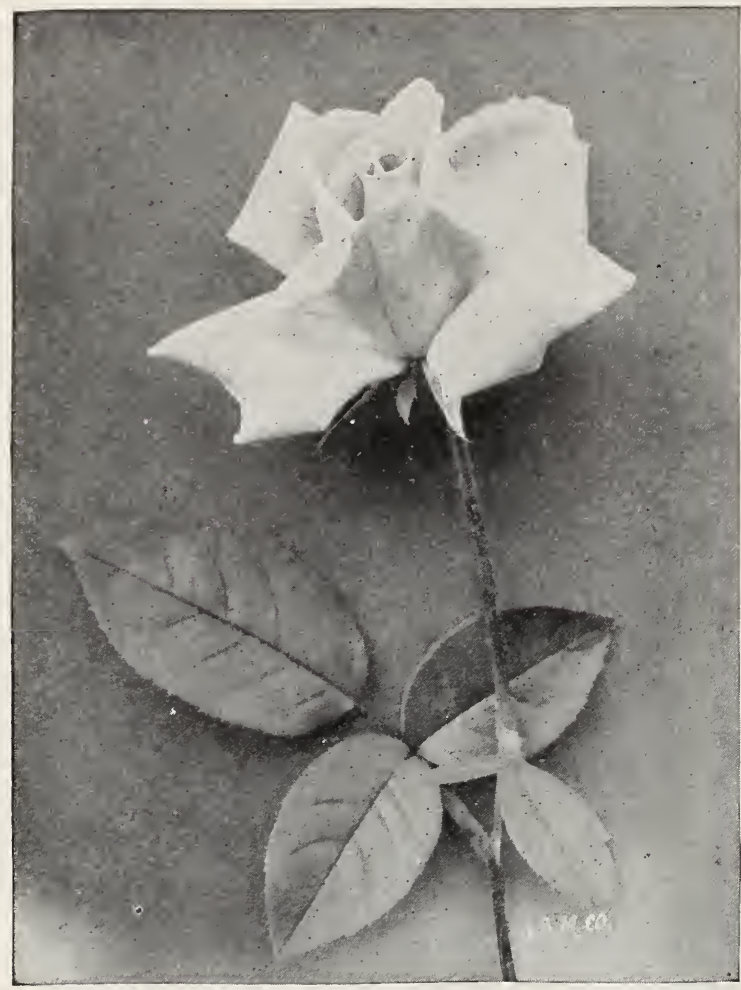

White Killarney.

\section{The Beautiful Irish Rose Pink Killarney}

This, the original introduction, is a beautiful Hybrid Tea Bush Rose; strong, sturdy and upright. with fine, heavy, insect-proof foliage, bearing flowers that are simply exquisite in form and color; the bud is exceedingly long and the flowers immense in size; color deep, brilliant, sparkling, shell-pink; hardy everywhere. The bush is magnificent in growth, of good size and bears its beautiful burden of flowers constantly all summer.

The exquisite shades of tender pink in this most beautiful Rose is hardly equaled by any other variety. Its very name conjures up all that is beautiful in poetry, and the flower is as beautiful as its name.

\section{White Killarney}

Identical with the parent variety, Pink Killarney, of which it is an offspring, except in color, which is glistening white. Like Pink Killarney, its great charm lies in the beautiful shape of its buds, so distinctive that everyone recognizes it as a Killarney by its shape. Enormous flowers, deliciously scented, and a new addition for which old Mother Nature is devoutly to be thanked.

\section{Double Pink Killarney}

The one great feature of this new Killarney Rose is that the flowers are furnished with almost twice as many petals as its famous and beautiful parent, Pink Killarney. Otherwise the Rose is identical with the parent variety. By some growers it is claimed that it is stronger in growth, but we can see no improvement in that direction, as the original Pink Killarney, is certainly not excelled in vigor of growth by any Rose in our collection, unless it misht be by Jeannette Heller, the most vigorous of all Roses. The bush is thoroughly hardy and in bloom continually all summer.

\section{Climbing Pink Killarney}

We claim the distinction of bringing this variety into prominence, and there is no Rose in the climbing class to compare with it. Hardy and everblooming, it is in a class of its own and has no rival; a strong, rapid grower, growing to perfection in the open ground, throwing up shoots ten to fifteen feet high in a single season. It produces its glorious blooms continuously throughout the year. Flowers are magnificent and immense, long, pointed buds with massive petals opening to flowers of enormous size, color brilliant, sparkling shellpink, deliciously fragrant; absolutely the best climbing Rose for all purposes known; hardy everywhere.

We have prepared an immense stock of all these famous Killarney Roses in the hope that we will have sufficient to meet the demand. Heretofore the demand has more than exceeded the supply causing disappointment both to our customers and ourselves. We urge early order's that we may have the plants for you. Price, 25c each: 2-year-old plants, 50c each; 3-year-old plants, $75 \mathrm{c}$ each, by express.

Prices of all Roses on this page, special size plants from pots 3 and $31 / 2$ inches in diameter, 25c each, postpaid; two-year-old plants, 50c each, by express, 


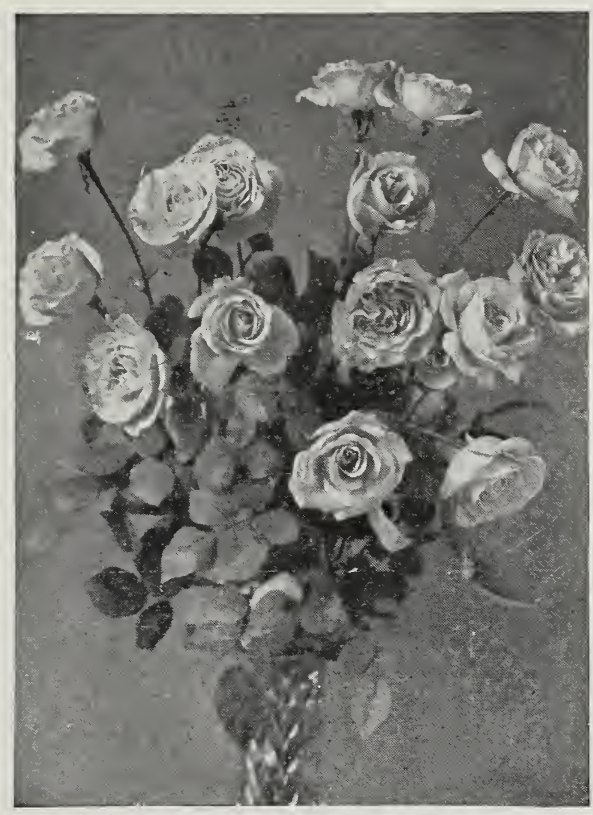

Mrs. David Jardine Roses

Robert Heller

The color of the flowers is deep golden yellow, occasionally, in the early stages of development, faintly tinged with pink, but as the flower develops fully it is pure golden yellow without a blemish. It will prove hardy in all sections of the country, except where the winters are extremely severe. Two-year-old plants, 50c each, by express.

Max Hesdorffer. New Hybrid Tea Rose. Forms a strong, sturdy bush with heavy, bright green foliage. Magnificent blooms of rosy pink.

Wellesley. A beautiful pink, very freeflowering and fine-keeping Rose of wonderful size and beauty. The bush is strong and sturdy.

General McArthur. One of the most vivid crimson-scarlet Roses in cultivation. Hardy in practically all localities, and as an outdoor Rose it has no superior. Every shoot carries a large, double, well-formed flower of exquisite fragrance.

Aurola. Flowers are double, very large and full; petals imbricated. Color rich, bright pink in center, paler outside.

Antoine Rivoire. Flowers exquisite in form, large, double and fragrant; rosy flesh with yellow ground, shaded with border of carmine.

\section{Mrs. David Jardine}

\section{A brilliant and most satisfactory Garden Rose}

One of the greatest pink Hybrid Tea Roses for forcing under glass, as well as a garden bush Rose of the first water. The blooms are large, of perfect form and produced on every shoot; very highly perfumed; color a delightful shade of bright, rosy pink, shading on the outer petals to salmon-pink. We have a magnificent lot of large, vigorous plants of this wonderful Rose, especially grown for fall planting. They are, without doubt, the finest Rose plants ever sent out by this or any other establishment, and they can be obtained nowhere else.

Kaiserin Augusta Victoria. The greatest hardy, white Hybrid Tea Rose in existence. A strong, sturdy grower; free flowering; it has become the most popular of all white Roses for general planting. Continuously from early spring until late fall, with pointed buds, the large, full double flowers are glorious in their perfection; delicate creamy white, deliciously fragrant. Unexcelled for cutting; absolutely hardy.

Rosenary. Shining silvery pink flowers of enormous size, with immense petals, absolutely double, on stiff, erect stems, in marvelous abundance; deliciously fragrant. Special-size plants.

Gruss an Teplitz. Fiery crimson, shaded with a dark velvety sheen. Large, handsome, moderately double flowers, produced in wonderful profusion throughout the whole season.

\section{Lady Faire}

A distinct new and rare Hybrid Tea Rose of a most brilliant, light carmine. The bush is a strong, sturdy grower, thriving with ordinary care and producing all summer a profusion of glorious flowers on long stems.

The flowers are produced in sprays of from seven to nine large, perfect blooms of semi-double form, of glowing apricot color, the petals assuming a primrose-yellow as the flower gets older; the bud is long and perfectly formed.

Wichita, Kans., May 1, 1912.

Heller Brothers Co., Newcastle, Ind.

Dear Sirs:-My roses arrived in fine condition. Thank you for extra one. Every one of the thirteen which came some weeks ago are growing fine, even the broken one grew. I will report what success I have with the blossoms later. Thank you for prompt and gentlemanly treatment. Most sincerely yours, Rev. D. H. M. Boyle.

Roses on this page are Bush Roses; prices, first size, strong plants, from pots not less than 3 and $3 \frac{1}{2}$ in. in diam., 25 each, postpaid; two-year-old plants, $45 c$ each, by express. 


\section{The Famous Cochet Roses}

Pink Maman Cochet. Clear, rich pink, changing to silvery rose.

White Maman Cochet. Snowwhite, with a pale blush.

Red Maman Cochet (Helen Gould). Flowers are very full, and of splendid substance; in color a warm, rosy crimson.

Yellow Maman Cochet. Deep silvery yellow. It has long been considered one of the very finest yellow Roses. Constantly in bloom.

Crimson Maman Cochet (Etoile de France). A handsomely formed, deep, velvety crimson Rose of exquisite fragrance.

SPECIAL OFFER: One of each of Pink, White, Red, Yellow and Crimson Cochet, special plants, $\$ 1.00$, postpaid; 2-year-old plants, $\$ 2$, by express.

Bon Silene. A grand old variety with great merit. Deep rose, changing to pale, light rose. Splendid for cutting. Fine in the open sround.

The Bride. Buds and flowers are unusually large, well-formed and deliciously perfumed. It is of a strong and healthy growth, and a profuse bloomer. A most exquisitely beautiful white Rose-a fitting companion to Bridesmaid.

Bridesmaid. Valuable for forcing and does finely in the open ground. Fine, clear, dark pink, so beautiful that it has caused "The Maid" to become one of the most popular Roses ever grown.

Clothilde Soupert. White, blended with delicate pink. Beautiful extra-hardy sort, sure to give satisfaction. It blooms the very first year it is set out. Flowers in clusters.

Devoniensis. Creamy white, with rosy center and very fragrant. Produces an abundance of large, very full and double flowers all through the season.

Duchesse de Brabant. The color is a fine shade of soft, rosy pink, which deepens to bright rose; beautiful in buds or open flowers; very vigorous and healthy. A special favorite.

\section{Frances E. Willard}

A beautiful white Rose of large size, perfect form and exquisite fragrance. The bush is strong, sturdy and erect, and very abundant and constant in bloom.

Mrs. B. R. Cant. It is strong-growing, exceedingly hardy, producing in marvelous profusion deep crimson-pink flowers, perfectly double; delightfully fragrant.

Reine Karola de Saxe. Great new garden Rose, flowers large and of a most dainty shade of blush white, tinted exquisite shellpink, borne in the greatest profusion. Delightfully fragrant.

Golden Gate. Color rich, creamy white, shaded with golden yellow and clear rose, with long and beautiful buds.

Souv. De Catherine Guillot. Coppery carmine shaded with pinkish orange. Most magnificent in size and color effect. The bush is sturdy, stout and vigorous, and always in bloom.

Safrano. Valued very highly for its beautiful buds and handsome flowers. Bright apricot-yellow passing to orange and fawn, sometimes tinted with rose.

All Roses offered on this page are bush Roses, large and free blooming.

\section{The Charming Baby Ramblers}

Crimson Baby Rambler. A delightful low-growing bush bearing constantly all summer splendid clusters of small, brilliant crimson flowers. One of the very best Roses for bedding or hedges.

Pink Baby Rambler (Anny Mueller). A handsome, everblooming bush covered with masses of dainty pink Roses.

White Baby Rambler (Catherine Zeimet), Similar in growth to the Crimson, but bearing fine clusters of dainty white Roses.

Phyllis. One of the most charming of all the Baby Ramblers, with clusters of large pink Roses beautiful in shape.

Mrs. W. H. Cutbush. A handsome bush bearing all summer a profusion of dainty pink Roses.

Pice of all Roses on this page, in special-size plants, from 3 -inch pots, 25c each, postpaid. Twoyear-old pot-grown plants, $45 \mathrm{c}$ each, by express. 


\section{Ivory}

\section{A Queen Among White Roses}

Golden Gate, known as the "White House Rose," has long been one of our best Roses, not only for outdoor planting but for cutting under glass. This beautiful new-comer is an offspring and identical with its parent variety, Golden Gate, except in color, which is ivory-white. Buds are of elegant shape, long and pointed; flowers full and double, with substantial petals, sturdy in growth, free flowering, with long, stiff stems.

Mrs. Aron Ward. One of the most beautiful of all Yellow Tea Roses. Coppery orange while in bud and blending out to pinkish fawn when fully developed.

Mme. Segond Weber. A beautiful new pink or salmon-flesh Rose. The bush is a fine strong grower, splendid for indoors, while for planting in the open ground it is magnificent.

Mrs. Dudley Cross. Pale chamois-yellow, beautifully illuminated deeper rainbow tints of rose and crimson. Extra-strong, specialsize plants.

Elise Heymann. New. A most beautiful Rose of chamois-yellow tint shaded with mankeen-yellow. Strong and vigorous.

Etoile de Lyon. Magnificent golden yellow. One of the hardiest of yellow Tea Roses. The plants make a strong, healthy growth.

Malmaison. Rich creamy flesh, distinctly and elegantly shaded clear peachy red, with a rose center; flowers very large.

Papa Gontier. Immense buds and magnificent flowers; color rich cherry-red, passing to clear, glowing crimson. A strong, vigorous grower and constant bloomer.

Perle des Jardins (Pearl of the Gardens). A beautiful shade of clear golden yellow, entirely distinct from any other variety; flowers large.

Souv. de Pierre Notting. Beautiful, clear apricot-yellow, tinged with golden, mixed with orange-yellow, edges of petals shaded carmine-rose.

Souv. de Stella Gray. New. Deep orange, with shading of yellow, apricot, salmon and crimson. Extremely vigorous.

The Orient. New. A handsome yellow Rose, varying in shade from pale lemon to deep orange. Foliage is glossy and handsome.

Price of all roses offered on this page in special size plants, $25 \mathrm{c}$ each, postpaid; twoyear-old plants, 45c each, by express. III Roses on this page are bush Roses, hardy and free blooming.

\section{Hardy Hybrid Perpetual Rose}

Coquette des Alpes. Large, full, finely formed flowers; pure white, sometimes tinged with pale blush; profuse bloomer.

Mme. Alfred Carriere. Color rich creamy white, faintly tinged with pale yellow; extra large and full; very double and sweet.

General Jacqueminot. The standard crimson Rose, and best for outdoor culture. It is a strong, vigorous grower, very hardy and a profuse bloomer. The flowers are unequaled in beauty of form.

Perle des Blanches. One of the finest pure white Hybrid Perpetuals; very freeblooming and strong-growing. Splendid for cemetery planting and for single specimens.

Black Prince. Much sought after because of its dark crimson flowers, which are shaded so deeply as to be almost black; large, full, cup shaped.

Prince Camille de Rohan. Deep, velvety crimson, shaded maroon and black. At a distance the beautiful, fragrant, large, deep double flowers appear black. A wonderful Rose.

Glory of the Exposition of Brussels. Deep, velvety purplish red, almost black; base of petals fiery red. Very fragrant. Large, full, double flowers. Hardy.

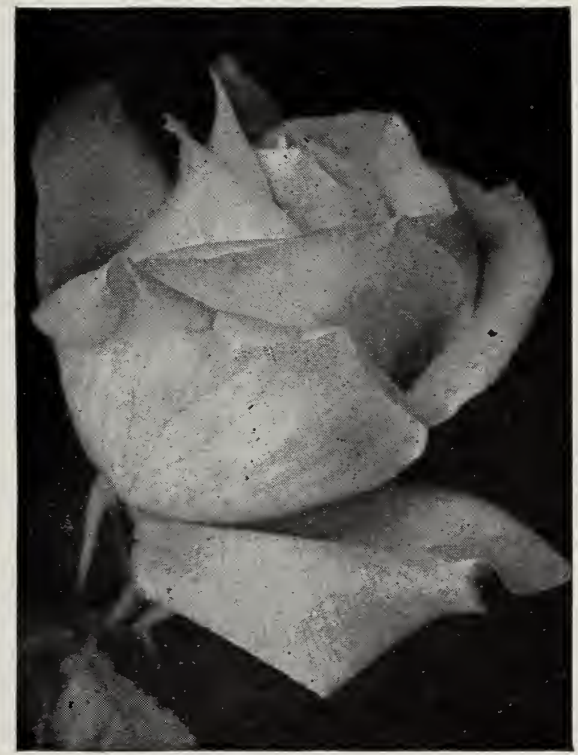

Perle des Jardins Rose 


\section{Hardy Climbing and Rambler Roses}

\section{Especially Prepared for Fall Planting}

\section{Alberic Barbier}

\section{A Great New Yellow Climbing Rose}

This is the very best hardy yellow Climbing Rose in cultivation and should be in every garden. Will grow in almost any soil or situation, good or bad. Entirely free from insect attacks, with beautiful, heavy, waxy foliage, which shines as if varnished. The beautiful yellow flowers are unusually full and double, and are produced sometimes singly and sometimes in clusters, with the utmost freedom.

Pliladelphia Crimson Rambler. This now famous variety differs from the old Crimson Rambler in having brighter, deeper and more intense crimson color. Blooming earlier than the Crimson Rambler, and entirely free from mildew.

White Rambler. (Thalia). Flowers pure white, sometimes tinted with blush.

Yellow Rambler. (Aglaia). Flowers deep yellow and very fragrant.

\section{American Pillar}

Strong grower, with pink flowers followed by red berries. A splendid climber with insect-proof foliage.

*Lyon Rambler. Immense, bright pink clusters; plant extremely vigorous.

\section{Lady Gay}

Deep, rich, rosy pink flowers. The plants are hardy and vigorous; foliage dark glossy green. It forms large, loose trusses, containing from fifty to one hundred brilliant flowers and elegant buds.

Evangeline. White single flowers, with tips of petals shaded pink. Vigorous grower.

Minnehaha. Beautiful foliage and elegant clusters of double satiny pink flowers produced in wonderful abundance.

Sweetheart. Bright pink shading to soft white when expanded. Hardy and vigorous.

Empress of China. The Apple-Blossom Rose. Soft dark red changing to light pink, like an apple blossom.

Prices of all Roses offered on this page in special size plants from $3 \frac{1}{2}$ inch pots, $25 \mathrm{c}$ each, postpaid; large two-year-old pot-grown plants particularly adapted for fall planting, $45 c$ each, by express.

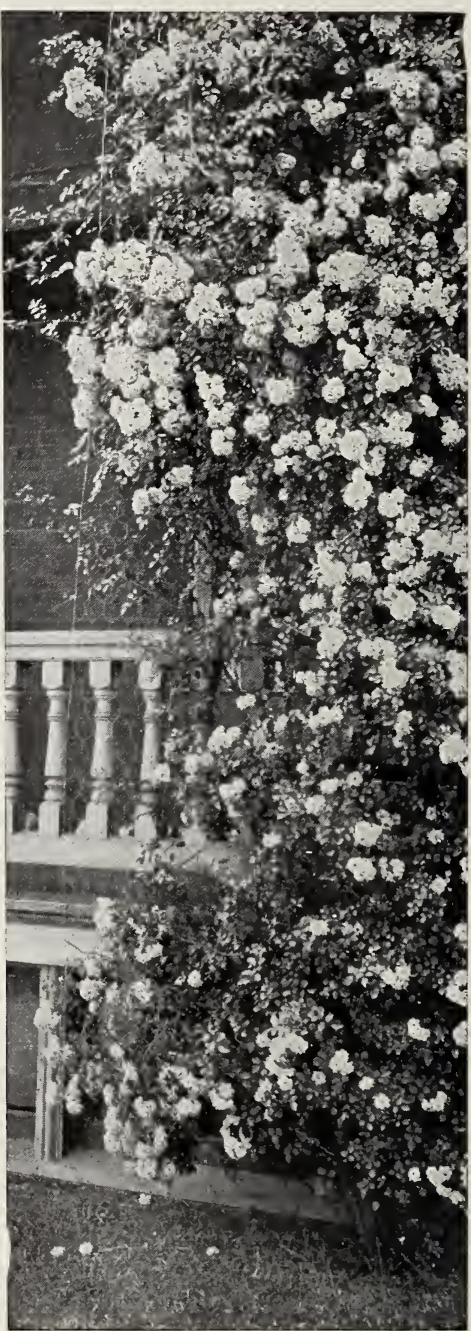

Alberic Barbier, great Climbing Rose.
New Hope, Pa., Mar. 18, 1912.

"It is with great pleasure that I send you my third order for roses. Nothing could give me greater satisfaction than did my roses last season. They were a riot of bloom from May to November.' Lettie Kinsey Betts.
Sumner, Wash., Apr. 23, 1912. The roses arrived in fine condition. I thank you very much for the extra climbers and the Jeannette Heller." Yours truly, Mrs. Fred Near 
Hardy Climbing Roses-Continued.

\section{Tausendschon}

A sensational new climbing Rose, producing on the same bush so many different colored flowers that it is impossible to describe the variations, hence the very fitting name, "Thousand Beauties." Blooming profusely from the beginning of June until the last of July, the double flower's appear in large clusters. The colors run from delicate balsam or tender rose through the intermediate shades of bright rose and carmine, with white and yellow tints showing. There is no other Rose in cultivation like it. It is a strong grower, with but few thorns, and absolutely hardy.

Keystone. A vigorous climbing Rose bearing clusters of deep lemon-yellow flower's of exquisite fragrance.

Lily Ito. A new Japanese climber bearing masses of dainty pearly-blush flowers all season.

Climbing Marie Guillot. Pure snow-white flowers. Bush is a rampant vigorous climber.

Climbing Metcor. A sport from Meteor, famous for its magnificent flowers. Dark, velvety crimson, the equal of any Rose in cultivation.

James Sprunt. A handsome climber bearing great clusters of double, deep cherry-red Roses which are of delightful fragrance. Rapid in growth and hardy.

Taunus Blumschen. A new rose-pink Rambler; a most profuse bloomer.

Goldfinch. One of the very latest introductions in Climbing Roses, bearing great clusters of brilliant golden yellow flowers, of a deep color when in bud, but opening lighter. The plant is a very vigorous, rampant grower, covering a great space in a remarkably short time and bearing most beautiful, fresh green foliage, not subject to insect attacks.

Everblooming Crimson Rambler. A rampant climber, bears continuously clusters of brilliant crimson flowers. Absolutely hardy everywhere.

Price of all Roses offered on this page in special size plants from $3 \frac{1}{2}$ inch pots, 25c each, postpaid; two-year-old, semi-dormant pot-plants, particularly adapted for fall planting, $40 \mathrm{c}$ each, by express.

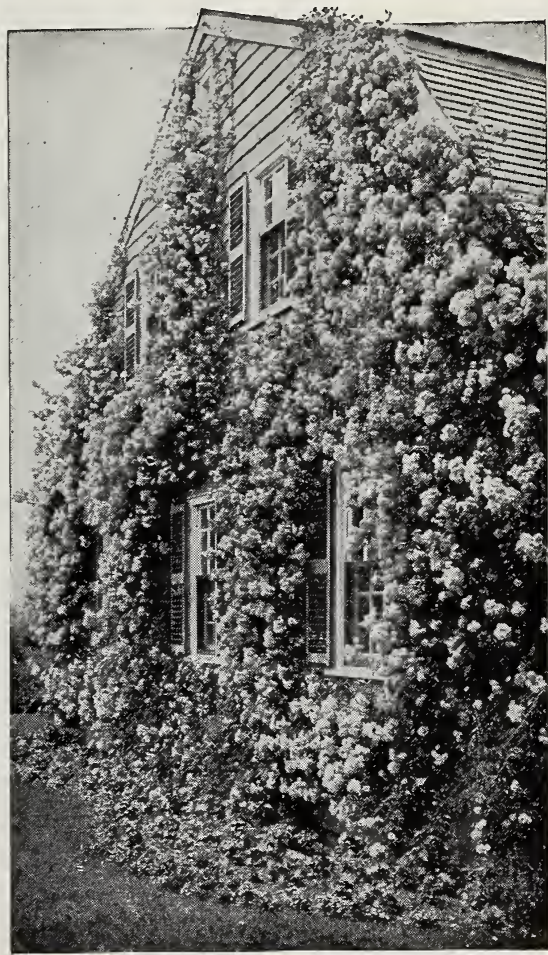

Tausendschon, or Thousand Beauties Rose.

\section{Climbing Clothilde Soupert}

One of the most satisfactory climbers, being in constant bloom and bearing a great profusion of handsome pearly-white roses with pink centers. A great Rose. Hardy everywhere. A single plant will cover an ordinary porch in one season.

Marechal Niel. Buds and flowers superb; extra large, very double, and deliciously perfumed. Deep golden yellow. Blooms with greatest freedom. Should have very careful protection. Splendid for house culture.

Heller Brothers Co., New Castle, Ind.

Zephyrhills, Fla., July 10 th, '12

Dear Sirs:- I received the additional roses last evening. Accept my thanks for the same. They came in good condition and I am sure they will grow as they are lovely strong plants. I especially want to thank you for the Crimson Baby Rambler, as that was an extra, and is a beautiful little plant.

Since I wrote you last month, the $25 \mathrm{th}$, I think, my Jeannette Heller, has sent out a cane that is fully four feet long, don't know where it is going to stop. When it gets started, I shall expect Robert Heller to grow as well. Am rather partial to boys, as I have one child and that a son, and I shall urge Robert to rival Jeannette. Thanking you again for the roses, I am, Respectfully yours, Mrs. T. K. Wilson.

Heller Brothers, Newcastle, Ind.

San Diego, Calif., Aug. 4, 1912

Gentlemen:-The 17 roses you sent me in May are all doing well some over two feet high now. There are four of them I wish you would tell me if they are running roses or not-Goldfinch, Fisher Holmes, Mrs. F. M. Flight, Madam Alfred Carrier. I wish you would send me catalogue as I wish to order more roses. Can I get roses this late in season? 


\section{Hardy Flowering Plants, Shrubs, Vines}

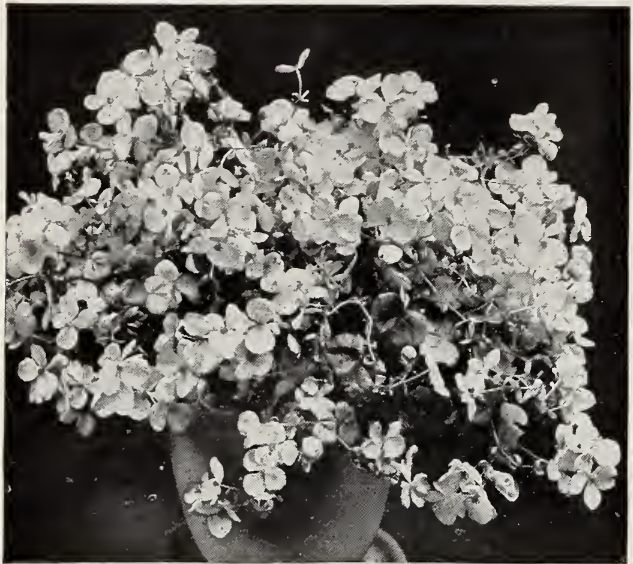

Begonia Gloire de Lorraine

\section{Begonia Gloire de Lorraine}

This magnificent Begonia is one of the most beautiful flowering plants now known, and the very finest of all plants for pots or boxes, being in constant bloom and bearing great masses of exquisite pink flowers above handsome green foliage. (See illustration.) Strong plants, $40 \mathrm{c}$ each; postpaid.

\section{Otaheite Orange}

A dwarf reproduction of the genuine fruit-bearing orange tree, the flowers being identical. It flowers and fruits in pots and blooms continuously. Fragrance is delicious. Fruits immediately after flowering and bears fruit and flowers at the same time. Strong, young plants, $15 \mathrm{c}$ each; 4 for $50 \mathrm{c}$; larger size plants, for immediateeffect, $50 \mathrm{c}$ each, by express.

\section{American Wonder Lemon}

A magnificent tub or pot plant, with large, dark green foliage and handsome, pure white flowers, nearly as large as tuberose blooms, fragrant as orange blossoms. Plant in ordinary soil, in a pot or tub. Not only ornamental, but useful. Very hardy. Strong plants, $20 \mathrm{c}$ each; 3 for $50 \mathrm{c}$; larger size, $25 \mathrm{c}$ each; 5 for $\$ 1$, postpaid; large pot plants, $75 \mathrm{c}$ each by express.

\section{California Privet}

Set Plants 8 to 12 Inches Apart.

The one best all-round Hedge-plant. Can be trimmed or sheared to any desired shape. Has splendid, dark green, glossy foliage. Hardy everywhere. First-size plants, 15c each; 9 for $\$ 1$; postpaid; $\$ 5$ per 100 , by express or freight; threeyear-old plants, 20c each; 6 for $\$ 1$; $\$ 10$ per 100 , by express or freight. Purchaser to pay express or freight charges in all cases. Orders for 50 100 rates.

\section{The Very Finest of All Palms}

Among the most satisfactory of all foliage plants for home adornment are the Palms listed below. They grow luxuriantly in the house during the winter and in summer make very decorative additions to the porch.

Kentia Belmoreana. The typical house Palm, growing tall, with long, drooping leaves.

Kentia Fosteriana. Like the former, but with broader leaves.

Areca Lutescens. Tall and slender in growth, with yellowish green trunk and stems and long, drooping leaves.

Latanica Borbonica. The "Fan Palm." Has very broad leaves on stiff stems.

Price of all Palms: Handsome, first-size plants, 25c each, postpaid.

\section{New Weeping Lantana}

Beautiful for baskets, vases, pots or for outdoor culture. Produces its clear lilac-pink flowers by the hundreds from early summer until severe frosts. Deliciously fragrant. Has a most graceful habit of growth. $15 \mathrm{c}$ each; 4 for $50 \mathrm{c}$; larger plants, 20c each; 3 for $50 \mathrm{c}$, postpaid.

\section{Clematis Paniculata}

We have a magnificent stock of this famous vine, in field-grown plants, now in pots for immediate delivery. No other vine grown will give you such abiding satisfaction as this, as it blooms freely the first season and increases rapidly in size each year. Strong, vigorous, one-yearold field-grown plants, now in pots, $15 \mathrm{c} ; 4$ for $50 \mathrm{c}$; larger size, $20 \mathrm{c}$ each; 3 for $50 \mathrm{c}$, postpaid; extralarge, two-year-old field-grown plants, now in pots, $35 \mathrm{c}$ each; 3 for $\$ 1$, by express.

\section{Hydrangea Panticulata Grandiflora}

The most ornamental of all Hardy Shrubs

The best known of all the Hydrangeas, with massive, cone-shaped clusters or panicles of flowers, borne in August and September. The flowers are white when first open, changing later to shades of bronzy pink and cling to the bush for weeks. The flowers are often used in their dry state for home adornment in winter. Can be used with splendid results in the formation of a flowering hedge.

Strong, well-rooted field plants, 20c each; 3 for 50c, postpaid; two-year-old, field-grown plants, with many branches, 50c each; extra-large, threeyear-old plants for immediate effect, 75e each, by express.

\section{Boston Ivy}

One of the finest vines for covering brick or stone walls, forming a perfect mat of dark green, lustrous foliage which turns to beautiful shades of crimson and scarlet in the fall, when it bears clusters of black berries or seeds. Strong plants, which will grow with wonderful rapidity $15 \mathrm{c}$ each; 4 for $50 \mathrm{c}$, postpaid; large, two-year-old plants, $50 \mathrm{c}$ each.

\section{Double Japan Snowball}

A most handsome summer-flowering shrub, with peculiarly crinkled foliage and bearing in early June a great profusion of snowball-like clusters of white flowers. Even when not in bloom, the bush is distinctly ornamental and adds a touch of unique effect to the garden.

Strong, field-grown plants, 25c each; 5 for $\$ 1$ postpaid: fine, large, two-year-old plants, fieldgrown, 40c each: 3 for $\$ 1$, by express.

This will serve as formal notice to our customers ordering hardy shrubs and climbing vines that this stock will be delivered as soon as it is ready for digging, which will probably be about November 1 , but we do not guarantee this. It is altogether dependent upon the weather. We will ship without further notice as soon as the plants are ready to dig. 


\section{Flowers for the Hardy Garden}

Price of all Peonies on this page, in strong, two- and three-eyed roots, $40 \mathrm{c}$ each; $\$ 4$ per dozen, assorted as clesired, postpaid, if by mail.

By many the Fall Planting of Perennial plants is considered best. As we see it, the great advantage is that the plant secures an early start the following spring which practically means a year's advantage in growth and bloom.

There is a constantly increasing demand for the old favorites in the gardens of long ago, and more and more the flower-lovers of our land are abandoning the use of annual flowers and are filling their gardens with hardy perennials-the kind that live from year to year, increasing in size and beauty until they fairly run riot with their wealth of bloom and glory of form and color. From the practical standpoint, these "old-fashioned" flowers are ideal either for him whose home is the midst of a vast estate or him whose "garden" consists of but a few feet of soil in a city back yard.

Of all the flowers in the Hardy Garden the Peony is easily recognized as the Queen-in fact it vies with the Rose for the title in many ways, for while in bloom it is without question the most glorious object in the garden. Once Peonies are planted they last for a lifetime. They stand the severest winters without the slightest protection. Especially fine for single specimens and cemetery planting. After blooming their charm lies in the beauty of its foliage, for even when not in bloom the Peony plant is decorative in the extreme and well worthy of a prominent place in the garden. Fall planting is especially recommended.

\section{Heller's Superb Peonies}

Peonies are ready for shipment as a rule about September $15 \mathrm{th}$ to October 1st. This is formal notice to our customers who order them of shipment, probably October 1 st at the latest. We do not guarantee this but will ship as soon as they are ready.

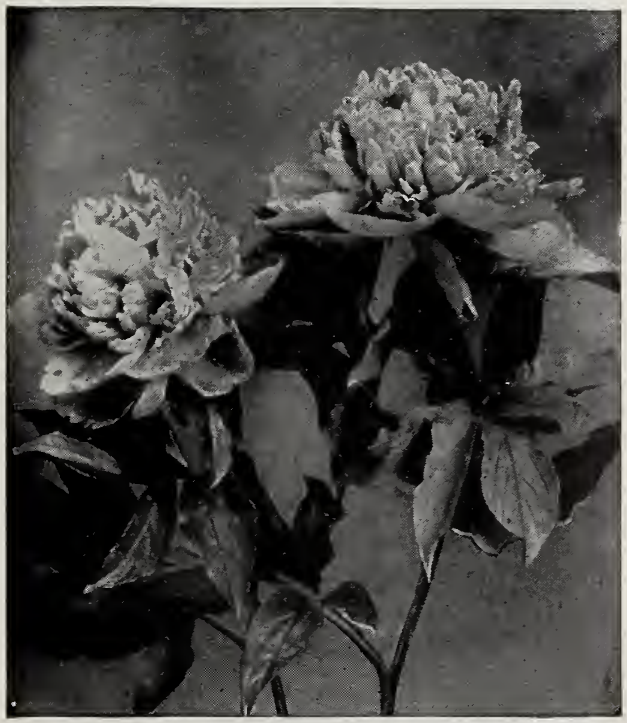

Peony-Modeste Guerin

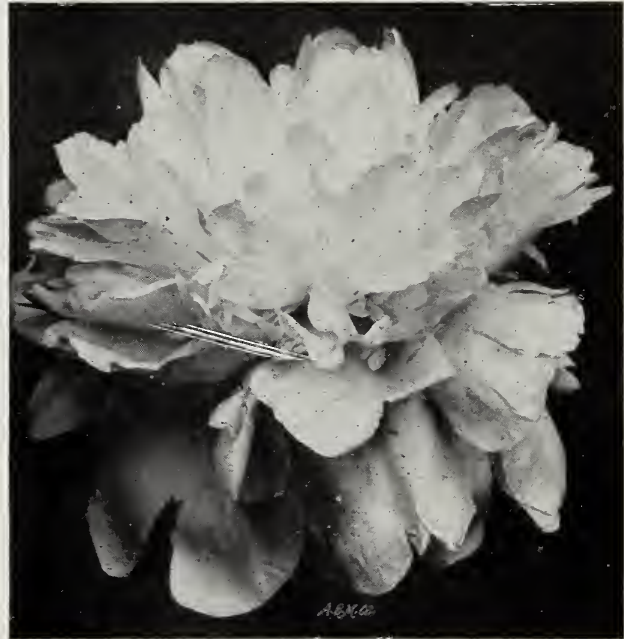

Peony-Festiva Maxima

Caroline Allain. Guard petals rose, center flesh and salmon.

Canary. White, with primrose center.

Candidissima. Creamy white, with sulphur-yellow center.

Delachi. Dark crimson; finely formed flower; free in bloom.

Duke of Wellington. Creamy white; very full and fragrant.

Edulis Superba. Soft pink, magnificent; one of the most popular.

Faust. Soft lilac guards, pink center.

Insignis. Violaceous pink.

Jeanne D'Are. Pink guard, sulphur collar and pink, tufted center.

Lady Bramwell. Splendid silvery rose, with large guard petals.

Louis Van Houtte. Velvety cerise-red; fine flowers.

Iodeste Guerin. Bright, purplish carmine; very large.

Nobilissima. Deep pink, with silvery border; large.

Prolifera Tricolor. Flesh-pink guards, center golden yellow; red tuft.

Festiva Maxima. Splendid white, with flakes of carmine on center petals. One of the finest. Very profuse in bloom; early and fragrant.

Rosea Humei. Rose-pink; very large; late; intense fragrance.

Rosea Elegans. Soft rose-pink.

Rubens. Very dark purple-maroon, with golden stamens.

Rubra Triumphans. Deep crimson-maroon; earliest of the crimson sorts.

Triomphe du Nord. Purplish pink, with fleshpink shadings.

\section{Old Fashioned "Pineys"}

These are the "Pineys" of the old-time garden -the varieties from which all the modern varieties have sprung-and bloom profusely in time for Memorial Day flowers.

Bright Crimson.. Splendid, large crimson; full.

White (Officinalis alba). White.

Rose-Colored. Flowers are bright, rosy red. 


\section{Heller's Glorious Irises}

\section{The Rainbow Flower of the Greeks and the Fleur de Lis of the French}

\section{Japanese Irises (Iris Kaempferi)}

Vie list our Japanese Irises under English names rather than the unpronounceable, albeit poetic, Japanese names. Our roots are all grown in this country and are far superior to those imported from Japan. Hardy everywhere and, once planted, they last a lifetime.

The stately dignity of the Iris, the gorgeous, royal coloring of the flowers, and the ease with which they are grown alike appeal to every lover of flowers. They increase in size and beauty with each succeeding year. Grows to perfection in ordinary garden soil and in the fullest sunlight. In fact, there are few plants which can adapt themselves so readily to the conditions to be met in the average garden.

\section{Double Varieties}

Excelsor. Shaded violet-purple, slightly veined white. Center white and orange.

Gold Bond. Pure white, one of the best.

La Favorite. Large, fine, white, freely veined blue.

Mahogany. Dark red, shaded maroon.

Oriole. Rich plum, marked yellow.

Pyranid. Lilac-blue, veined, white center, each petal.

Spotted Beauty. Wavy, silky white, spotted with violet-crimson.

Victor. White, veined violet-purple.

\section{Single Varieties}

Apollo. Pure white, pink center.

Granite. Grayish white, overlaid blue.

H. Von Sieboldt. Reddish, veined white, yellow center.

Lavender Queen. Fine lavender.

Lovelocks. Deep reddish purple, slightly veined white. Center white and yellow, satiny finish.

Mirage. Light pink, suffused with light blue.

Mars. Reddish purple, striped and blotched white.

Ondine. White, shaded light blue towards center.

Plume. White, slightly suffused with blue, violet veins. Center deep lilac.

Snowbound. Large, pure white, with golden bands.

Toledo. White, light purple center.

Price of Japanese Irises, in strong, vigorous roots, sure to bloom and true to name, 25 cts. each; any 5 for $\$ 1 ; \$ 2.50$ per dozen, postpaid, if by mail.

\section{German Iris}

The memory of the "Blug Flag" of the oldtime gardens is one that is ever dear to us.

Both Japanese and German Iris are entirely hardy everywhere-once planted, are practically permanent. Require no petting or coaxing. Simply plant them-they will do the rest.

Alvelrea. Upright petals light blue, edgod with azure-blue, falls white.

Candiamus. Light lavender; falls reddish purpure.

Florentina. Creamy white, fragrant and early. Fine cutting.

Fragrance. White edged with blue.

Honorable. Intense yellow, falls a beautiful bronze.

Innocence. White edged with blue.

Madam Chereaii. Pure white.

Irs. H. Darwin. Fine, large, white.

Neclecta. Stands fine blue; falls deep blue,

Large flowers,
Pallida Dalmatica. Very large, sky blue and fragrant.

Parkmani. Stands pure lemon; falls whice veined purple.

Pearl. Light lavender, falls deeper.

Penelope. Stands nearly white, falls veined lively purple.

Queen of the Gypsies. Dusky light bronze; falls purplish red.

Sans Souci. Yellow, elegantly reticulated light maroon.

Souvenir. Stands brilliant yellow; falls network of yellow and purple.

Stenophylla. Light blue.

Velveteen. Yellowish buff; falls intense plumpurple.

Price: Strong, healthy roots, true to name and sure to bloom, $20 \mathrm{cts}$. each; $\$ 2$ per dozen, in one or assorted kinds, prepaid, if by mail

Special Offer: One each of the above 18 varieties for $\$ 2.75$, postpaid, if by mail.

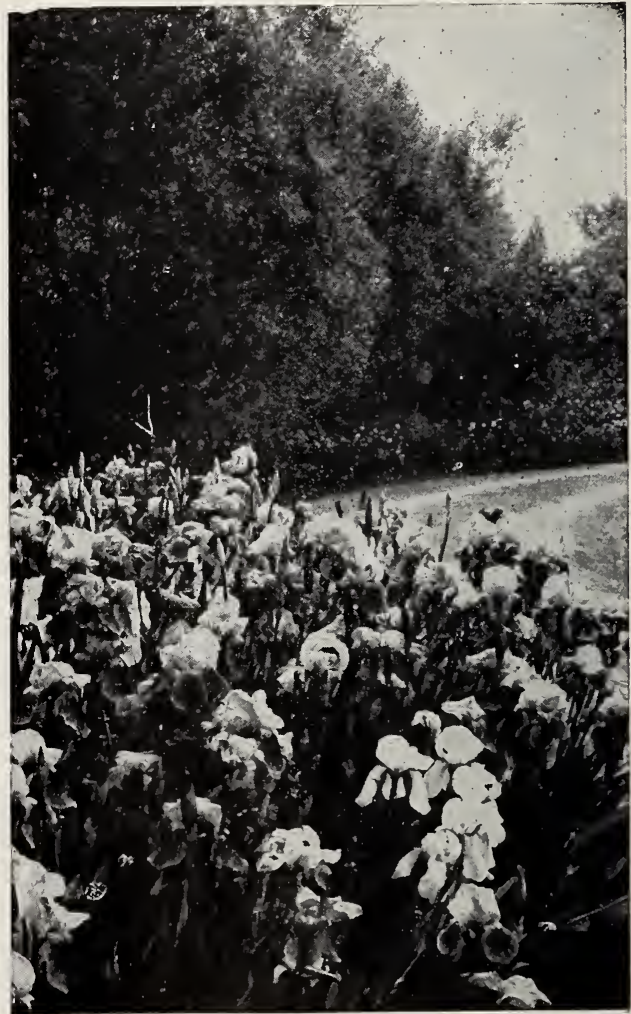

Iris Planting 


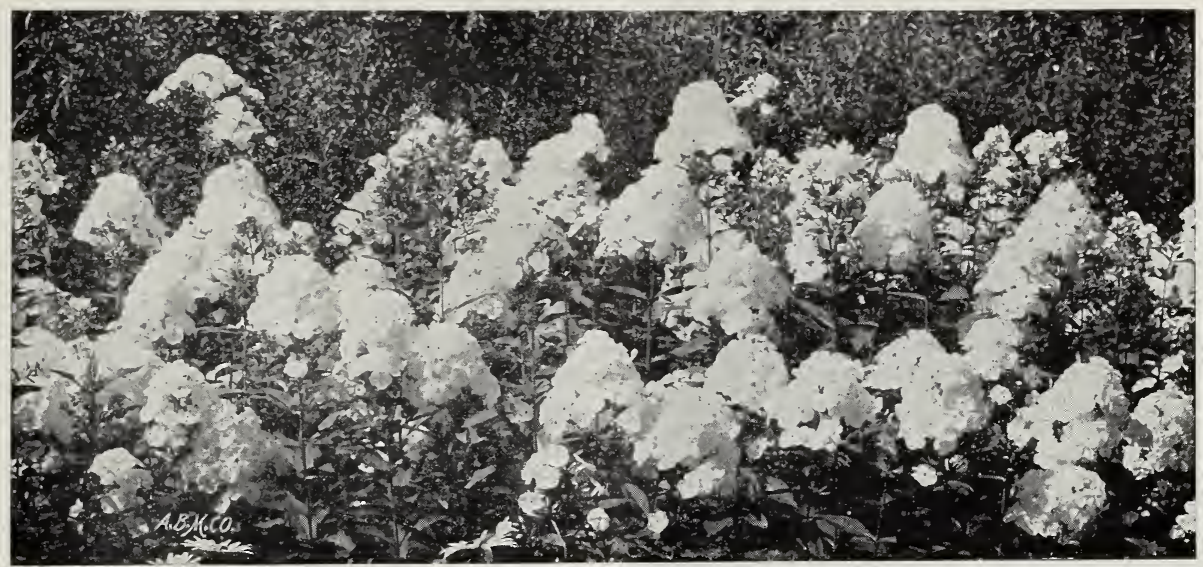

Hardy Perennial Phlox

\section{Hardy Perennial Phlox}

Phlox is the easiest of all hardy flowers to grow, and which will fill your garden with the glory of summer in a way that will be a revelation to you. Fall planting especially desirable-a year's growth is then gained.

In no other hardy flower of the old-fashioned garden has there been a greater evolution than in the beautiful Hardy Perennial Phlox. The colors range in all imaginable shades from snow-white to a crimson almost black in its intensity. And there is a bewildering variety of arrangement of color-some varieties are solid masses of a single color, others are distinguished by the handsome "eye" or center of the individual flower, while others are daintily marked with a "halo" around the center, giving them a distinctiveness all their own.

The blooming of the Hardy Phlox is an event to which the flower-lover looks forward with impatience, as no flower in the hardy garden will give such a lavish display and fill the garden with such a wealth of color and magnificence of bloom.

We carry absolutely the best and choicest varieties in cultivation. We offer these in strong plants which will bloom profusely in the coming summer and keep up a succession of handsome flowers from June until frost. Plant at once.

Beranger. White, suffused with pink; rose eye.

Boule de Feu. Deep red; dwarf; large flowers.

Brilliant. Bright, clear red; extra fine.

Coquelicot. Bright orange-scarlet; extra fine.

Cortez. Deep, shining red; very large.

Diadem. Pure white; low growing; large.

Eclaireur. Rosy magenta with lighter halo.

Iris. Bluish violet; very tall and large.

L'Aiglon. Carmine-rose, darker center; tall.

Mont Sully. Orange-scarlet with purple eye.

Perle Rose. Rose-purple; very striking.

Rachel. Rose-pink with purple eye.

Selma. Pale rose: very tall; fine flowers.

Suffrage. Lilac-mauve with rosy center.

Tapis Blanc. Pure white; dwarf; large flowers.

Price of Hardy Perennial Phlox, in strong, vigorous plants, 20c each; $\$ 2.00$ per dozen, postpaid; $\$ 10$ per 100 by express.

Special Offer: One each of the entire list of Hardy Perennial Phlox above, 15 varieties, all correctly labeled. $\$ 1.75$; two plants of each, 30 in all, \$3.25, postpaid. This is the greatest offer in these wonderful plants ever made.

\section{Violets}

Almost before the spring snows cease the Violet will be found braving the chilly air and sending up its dainty, sweet-smelling flowers as harbingers of the slory of the garden to follow. Some of the varieties bloom more or less sparingly during the summer, while Marie Lynch will yield a profusion of flowers late in September and October.

Marie Lynch. Of all the Violets grown this is the sweetest, daintiest and most beautiful, with a perfume simply exquisite. In color, it is a charming shade of lavender-pink and the foliage is rich, dark green.

Peacock. Beautiful blue with white center.

Swanley White. Pure white, perfectly double; fragrant.

Iady Hume Campbell. The finest double blue Violet, large and sweet-scented.

California. The largest of all; rich, violet blue, immense single flowers.

Price: Strong Violet plants 10c each; 3 for $25 \mathrm{c}$; any 7 for $50 c$; any 15 for $\$ 1$, postpaid; $\$ 6$ per 100 by express; larger plants or clumps, 20c each; 6 for $\$ 1$, postpaid; $\$ 12$ per 100 , by express.

\section{New Castle Lawn Grass Seeds}

One feature of this, the Rose City, where American Beauties are grown by the million each year, is its lawns, the result of planting our wonderful mixture of grass seeds, which we have named the New Castle Mixture. It is, without exception, the best for general sowing, and produces a smooth, velvety green sward. It is particularly valuable for sowing in the fall, from September to as late as the weather continues warm. It is a good idea to have a supply of it on hand over winter to sprinkle upon the top of the February snow when it will be carried into the ground as the snow melts. Price, by mail, 45 cts. per pound; by express, charges collect, 35 cts. per pound. 


\section{Heller's Handsome Carnations}

Carnations are among the handsomest of all flowers, and our extra-strong, stocky plants will bloom profusely all summer. The flowers are superb and have an exquisite clove fragrance. Bring indoors in early fall. Grown in pots they will bloom abundantly during the winter. We offer the newest and best varieties now grown.

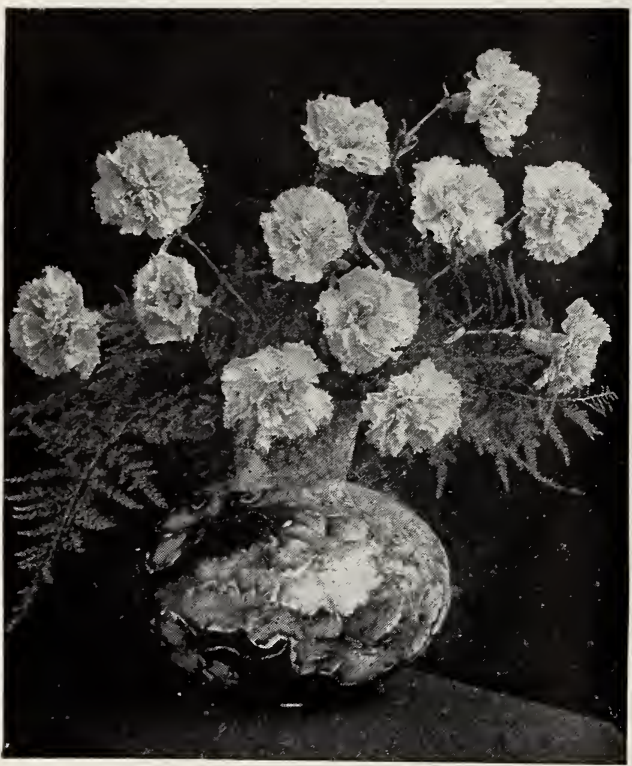

Carnations and Asparagus plumosus

Admiration (new). Brilliant red. Strong in growth and free in bloom.

Apple Blossom (new). Handsome white flower, daintily marked pink.

Beacon. Dazzling scarlet; very large and full.

Boston Market. Standard white.

Lawson Enchantress. Brilliant pink; fine shade; large size.

Rose-Pink Enchantress. Deeper pink than Enchantress.

Victory. Brilliant red; extra-large flower and particularly free in bloom.

White Enchantress. A magnificent large, white flower of splendid form.

White Perfection. Clear, brilliant white; fine form and very large.

W. H. Taft (new). Brilliant pink; splendid size and form.

Mrs. Patten (new). White, beautifully marked with pink.

Afterglow (new). Clear, rose pink; exquisite.

Conquest (new). Beautifully variegated; white and red.

Mrs. Bassett (new). Beautiful crimson, scarlet; extra large.

Georgia (new). A great new white; exquisite.

Price: Strong, vigorous, field-grown plants, especially for winter blooming, prepared indoors, 30 cts. each, \$3 per dozen, postpaid, in one or assorted varieties, purchaser's selection.

SPECIAL Offer: For $\$ 3.60$ we will send postpaid 15 plants of the above varieties, our selection, all correctly labeled.

\section{Heller's Beautiful Ferns}

There is a charm about the Fern for home adornment hard to equal with any other plant, with their long sprays of fresh, lively, green, handsome foliage. Even the smallest plants will in a short time grow into magnificent specimens. They are of the easiest culture, requiring little or no care, and will last indefinitely.

Boston Fern. Long, broad fronds, drooping gracefully and forming a plant of immense size.

Dwarf Boston Fern (Scotti). Dwarf growing and compact.

Crested Dwarf Boston (Schotzeli). A beautiful, fluffy dwarf Fern, with each frond curled and crinkled.

Whitman's Lace Fern (Whitmanii). Most beautifully cut and frilled foliage, the fronds being large and broad.

Philadelphia Lace Fern. (Amerpohli). Delicately cut fronds.

Pierson's Fern (Piersonii), Ostrich Plume Fern. Beautifully frilled, and the fronds arch over in a most graceful manner.
Price of all Ferns, strong, shapely plants, 15 ets. each; any 4 for 50 cts.; larger size, 25 cts. each; extra large, two-year-old plants, splendid specimens, 35 cts. each, postpaid.

\section{Japanese Fern Ball}

When suspended and kept moist it breaks out into a mass of dainty, lace-like, fern foliage, forming a beautiful ball of green. Keep it moist with occasional sprinklings and do not allow it to become dry. Good, fresh balls, just imported, 5 inches and more in diameter, $40 \mathrm{c}$ each; 2 for $75 \mathrm{c}$; larger size, $7 \times 9$ inches, $65 \mathrm{c}$ each; 2 for $\$ 1$, postpaid.
Springfield, Mo., July 28, 1912. Heller Brothers Co., Newcastle, Ind.

Gentlemen:- The Pierson fern which I ordered arrived in good condition and straightway began to make prodigious growth.

Yours for future business,
Pittsburgh, Penn., June 15, 1912.

"The plants are doing splendid and I don't see why all lovers of flowers do not place their orders with Heller Bros. for they do more than they promise. I can prove it."

A. B. Gardner. 


\section{Hardy Perennials for Fall Planting}

Price of all hardy perennials on this page, in strong, vigorous, well-rooted plants, 20c each; 3 for 50c; $\$ 2.25$ per dozen, postpaid; in one or assorted varieties as desired.

BLOOMING IN APRIL

American Red Columbine. Flowers have yellow cups and scarlet spurs and nod gracefully on the ends of long stems.

\section{BLOOMING IN MAY}

Rocky Mountain Columbine. Blue flowers two inches across. with long spurs.

Golden-spurred Columbine. Grows three to four feet high with bright golden flowers bearing long and spreading spurs. Blooms continuously all summer.

Sweet Rocket. A tall-growing plant bearing clusters of dainty small flowers ranging in color from white to purple. Blooms all summer.

old-fashioned Peonies. See under the head of Peonies, page 19.

German Iris. See under the head of Iris, page 20.

Lily of the Valley. Dainty sprays of white, bellshaped flowers and broad foliage. Supplied only in "pips." 3 for $15 \mathrm{c} ; 50 \mathrm{c}$ per doz.; $\$ 3$ per 100 , postpaid.

Hardy Pink-Double Scotch. White and pink flowers like small carnations; low-growing plants used for edges. Evergreen foliage. Don't cover in winter.

Hardy Pink-Pheasant's Eye. Like the former, but with deeper-colored flowers of pink and red. Garden Heliotrope. A rapidly spreading plant of low growth, bearing clusters of sweet-scented sinall white flowers.

Forget-Me-Not. Low growing, spreading plant with a profusion of dainty blue, five-petaled flowers, with yellow eyes.

Óriental Poppy. Magnificent, large, striking flowers of gorgeous shades of red. Flowers grow on long stems. Foliage rough; dies down in summer

\section{BLOOMING IN JUNE}

White Tansy or Yarrow. (The Pearl). Handsome clusters of white flowers on long stems, forming splendid sprays for cutting. Blooms all summer.

Alkanet. (Dropmore Variety). Tall-growing plant, with rough foliage and bearing large heads of deep-blue flowers. Fine for the back of the border or amongst shrubbery. Blooms continuously to September.

Canterbury Bells. Tall and majestic plants bearing large clusters of beautiful, blue, bellshaped flowers. Fine for cutting.

Cup and Saucer. Quaint, old-fashioned flowers resembling a cup and saucer, in colors varying from white to pink and blue.

Tickseed. Handsome plants growing a foot or two high and bearing great masses of bright-yellow ray-form flowers. Will bloom again in fall. Larkspur. Handsome spikes of bright blue flowers growing three to four feet high. If cut when first in bloom, more flowers appear in the fall.

Sweet William. Handsome clusters of flowers of all shades, from white to deep, dark red. One of the best known of all hardy garden flowers. Both single and double. Blooms all summer.

Foxglove. Gorgeous spikes of tubular flowers in shades of white and rose and purple, curiously mottled and marked. Grows four to five feet tall, and is most majestic in effect.

Pyrethrum, Most attractive, ray-form flowers, varying in appearance from that of an enlarged single daisy to a flat, double chrysanthemum. All colors, white to deep red. One of the most satistying of all perennials.

Late Peonies. Named varieties. See under the head of Peonies, page 19.

Hardy Phlox. Early varieties. See Hardy Perennial Phlox, page 19.
Japanese Iris. See under the head of Iris, page 20 . Some of the Japanese Iris bloom well into July.

Showy Coneflower. Handsome plant, two to three feet high, with many branching stems, and bearing great quantities of brilliant yellow, ray flowers with brownish purple centers, like an enlarged "Black-eyed Susan"

Purple Coneflower. Brilliant orange-colored ray flowers with purple, cone-shaped discs. Grows very tall and bears a profusion of flowers like small sun-flowers. Fine for cutting.

Narrow-leaved Yucea. Splendid decorative plants with long, narrow leaves and throwing up from the cente: a magnificent spike of white, bellshaped flowers.

Variegated-leaved Yucca. A form of the "Adams' Needle," with striped foliage and great spikes of flowers.

\section{BLOONING IN JULY}

Blanket Flower. Magnificent, large ray-form flowers of a tawny orange, with purple dises. Blooms constantly until September.

Maltese Cross. Splendid, tall plants, bearing clusters of vivid scarlet flowers, each one like Maltese Cross in shape. One of the favorites of the old-time gardens.

Japanese Iris, Late Varieties. See under the head of iris, page 20.

Hardy Phlox. Mid-season varieties. See Hardy Perennial Phlox, page 21.

Evening Primrose. Large plants with bright golden yellow flowers, opening as the sun goes down.

Cinquefoil. Mixed varieties. Handsome, upright plant with single, five petaled flowers in all shades of red. Very effective and blooms through August.

Marguerite, or Paris Daisy. Large, daisy-like flowers and finely cut foliage. Splendid for cutting.

\section{BLOOMING IN AUGUST}

Mallow Crimson-Eye. Magnificent, large, creamy white flowers, with five broad petals and large, crimson centers.

Baby's Breath. A tall-growing plant bearing the greatest profusion of small, white flowers, creating a mist-like effect over the plant, giving it its poetic name.

Hollyhocks. The old fashioned varieties in all colors.

\section{BLOOMING IN SEPTEMBER AND OCTOBER}

Windflower. Most beautiful plants with grapelike foliage and bearing chaste and exquisite broad white flowers until frost. The plants grow tall and should be set well back in the border. One of the handsomest of all hardy flowers.

Hardy Chrysanthemums. Pompon Varieties. These old favorites of long age are still among the most popular of all hardy flowers, and carry the blooming season well into the fall, oftentimes being in full bloom when the first snow falls.

Varieties of Pompon Chrysanthemums

Acto. Dahlia-like petals; bright rose.

Alma. Pink; extra large.

Baby. Golden buttons; very late.

Bessie Flight, Rosy heliotrope; very large.

Garza. Snow-white; single; yellow center.

Magnificus. Pure white; extra large.

Mignonette. Yellow; feathery in effect.

Savannah. Yellow; extra large and fine.

SPECIAL OFFER:-We will send 12 hardy perennials, extra heavy strong plants, our selection, postpaid by mail for $\$ 1.50$. This is a great bargain. Now is the proper time to plant perennials. 


\section{Heller's Choicest Geraniums}

The most easily grown of all flowering plants. Particularly fine for bedding or for growing in porch and window boxes; in fact, where a quick, brilliant effect is wanted, Geraniums are unsurpassed. The

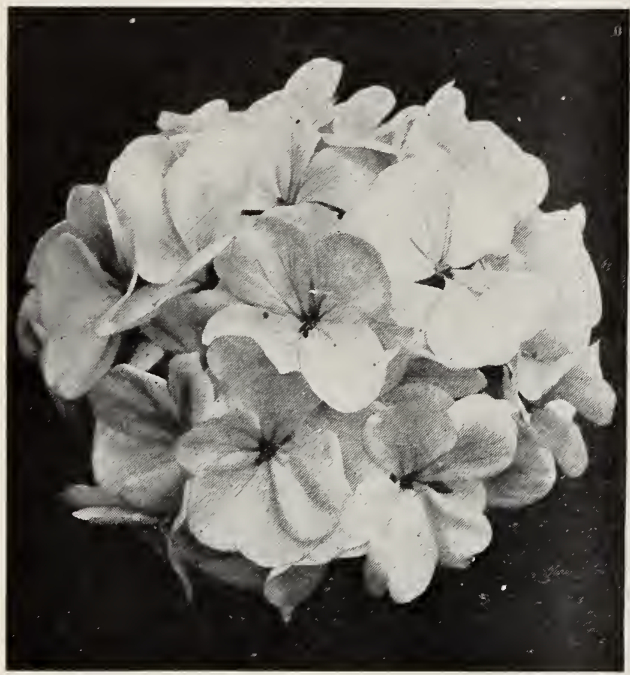

Heller's Single Geranium

Alphonse Ricard. Double; bright vermilion.

Beaute Poitevine. Double; shrimp-pink, shading to white.

Berthe de Presilly. Semi-double; silvery rosepink.

Contesse de Harcourt. Double; pure white.

Dagata. Semi-double; mauve-rose, with large blotches of white at base of upper petals.

Dryden. Single; white center, shading through a delicate lilac toward outer edge of petals, which are glowing soft crimson.

E. H. Trego. Semi-double; dazzling scarlet, pleasing velvety finish on saffron ground.

Jean Oberle. Semi-double; peach-pink, gradually shading to almost pure white at outer edge of petals.

Jean Viaud. Double; bright, clear shade of mauve-rose, shading to a. clear white throat.

La Favorite. Double; pure white.

Leon Baudrier. Semi-double; carmine-lake shading soít cerise to a large white center.

Iadame Recamier. Double; snow-white.

Iadame Salleroi. Variegated foliage, bright green, edged with white. Excellent for planting
in large beds.

Montmort. Double; deep, brilliant purple.

Mrs. Lawrence. Double; bright, satiny salmonpink, slightly tinged white.

S. A. Nutt. Double; dark red.

Thomas Meehan. Single; brilliant rose-pink.

Price: Strong, thrifty plants, ready for immediate effect, 15 cts. each:" $\$ 1.50$ per dozen, in one or assorted varieties, postpaid.

SPECIAL OFFER: One each of the entire list of 17 varieties named above, in stout, thrifty plants, each one labeled, $\$ 2$, postpaid.

\section{Miscellaneous Plants and Vines}

\section{Sweet-Scented Jessamine}

Charming pot plants, constantly in bloom and bearing a profusion of thick-petaled flowers of wonderful fragrance. One plant will perfume a làrge room.

Price, all varieties, 20 cts. each; 3 for 50 cts., pustpaid.

Maid of Orleans. Large, double white flowers. Gracillium. Snow-white flowers, in clusters; foliage graceful and somewhat twining. Can be trained over a window in a charming way.

Grandiflorum. Flowers star-shaped, pure white. Revolutum. Of climbing habit with bright yellow flowers.

\section{Asparagus Plumosus \\ Lace Fern}

A handsome, fern-like plant with fine, feathery foliage resembling the finest lace. The graceful fronds are often used with splendid effect with cut-flowers. Strong plants, $15 \mathrm{c}$ each; 4 for $50 \mathrm{c}$, postpaid.

\section{Smilax}

\section{For the Window Garden}

A handsome climbing vine with beautiful, glossy green, heart-shaped leaves, which can be trained with splendid effect over the window. The foliage is often used with cut-flowers. Strong plants, $15 \mathrm{c}$ each: 4 for $50 \mathrm{c}$, postpaid.

Sanseviera Zealanica. Long, leathery leaves, marked with silvery gray and standing upright. $15 \mathrm{c}$ each; 4 for $50 \mathrm{c}$, postpaid.

\section{Asparagus Sprengeri}

\section{Enerald Feather}

One of the most graceful of all house plants for growing either in a hanging basket or a vase set upon a high standard. The long, slender stems, carrying great masses of handsome, feathery foliage, grow four to five feet long and hang in graceful festoons. The plant is very quick in growth and soon forms a splendid. specimen. Fine, strong plants, $15 \mathrm{c}$ each; 6 : for $\$ 1$; large, two-yearold plants, $40 \mathrm{c}$ each, postpaid.

\section{Geranium-Sallero1}

Effective in a dozen different ways. Bright green foliage heavily edged with white-beautifu and unique. Used universally for bedding effects, in solid masses and for edging beds of Cannas, Salvias, Geraniums, Roses, Violets, etc. No other plant so effective. A mass of Scarlet Sage edged with Salleroi Geranium is the most brilliant, cheapest and best of all decoration. Try them. An inexpensive and most beautiful center piece for the dining table (and let credit for this discovery be given where it belongs-to. the good wife of the writer) can be had by using an ordinary Fern dish,-cost $10 \mathrm{c}-$ one $35 \mathrm{c}$ size Salleroi for the center and about two each Asparagus Sprengeri and Plumosus, $15 \mathrm{c}$ size around the edge-total about $\$ 1.00$-effect $\$ 5.00$. Try it. The idea is not copyrighted.

Prices: Strong plants, 15c each; 10 for $\$ 1.00$ larger plants, 25, each; 6 for $\$ 1.00$, postpaid; large specimen, two-year-old plants, $35 \mathrm{c}$ each, by express. 


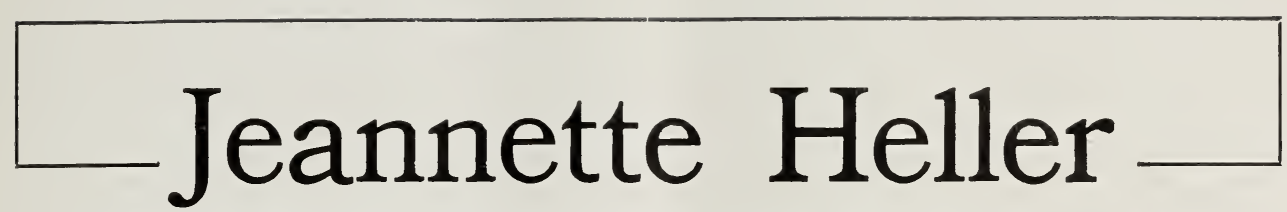

\section{Our Sensational New Rose. Best in the World for Autumn Planting. As Easily Grown as a Geranium}

\section{See Photographic Illustration in Colors, next Page}

$\mathrm{N}^{\circ}$ O PEN picture or even colored photograph can do justice to this wonderful new, hardy, everblooming Rose. It is the most marvelous variety ever introduced, and we pronounce it, as does every expert who has seen it, to be a b s o lutely the greatest Rose in the world. We stake our reputation upon this assertion, knowing full well that all who plant it will share with us in our genuine ienthusiasm over it. We want every one of our customers to plant Jeannette Heller. There is no other Rose like it, either in color, growth or beauty, and where ever seen it has created a veritable sensation.

Jeannette Heller is the ideal garden Rose, strong and vigorous in growth, healthy in every condition, growing in practically any soil or situation under the most adverse conditions to a perfection scen in no other Rose. Neither heat nor cold affects it, and if it has an ailment or a defect of constitution of any kind, we have yet to see it. To use a homely comparison, it "grows like a weed," throwing up with the greatest freedom wonderfully strong, stiff, sturdy canes.

The flowers, which are the glory of the plant, are produced in amazing profusion; in fact, no Rose of any class will compare with it in freedom of bloom. They are immense in size, so filled with petals that they last for days after cutting. The color is a beautiful blending of shell-pink in the center, shading off into rosy blush and pale yellow, difficult to describe and to illustrate. The color effect, however, is exquisitely beautiful; the buds are long and pointed and of immense size. Hardy in all localities, as it has been tested throughout the entire United States under the widest variety of conditions, and the reports from our patrons who have grown this rose have been uniformly enthusiastic and favorable.

For single specimens or for hedges or be d s, where it grows to a height, when fully developed, of 3 to 4 feet, it is the superior of a $n \mathrm{y}$ Rose in existence. Flowers may be cut from it early in May, and they are produced with the $\mathrm{u} \mathrm{t} \mathrm{mos} \mathrm{t}$ freedom throughout the entire growing season until cut down by severe frosts.

We $r$ e peatJeanette Heller is the premier garden Rose of today, and if we never were to introduce another new Rose, we are convinced that this Rose has brought us everlasting fame as the greatest Rose introduction of this century.

For winter blooming indoors it is the best of all Roses. Is easy to grow as a Geranium and equally as free blooming.

We have a magnificent stock of this popular rose especially prepared for planting this fall and urge all our patrons not to fail to secure their plants now and you will be rewarded ten-fold next spring.

\footnotetext{
"I was pleased to get my order. The Jeanette Heller came through the winter better than any of them." MRS. M. E. ARNOLD.

Cathlamet, Washington, July 27, 1912.
}

First size, strong pot-plants, special size, 25c each, postpaid; two-year-old plants, 50c each; \$5 per dozen: 3-year-old specimen plants (limited quantity), 75c each; \$8 per dozen, by express. IIL ON OWN ROOTS. 
Wonderful, New, Alardy, Everblooming Bush Rose JEANNETTE HELLER

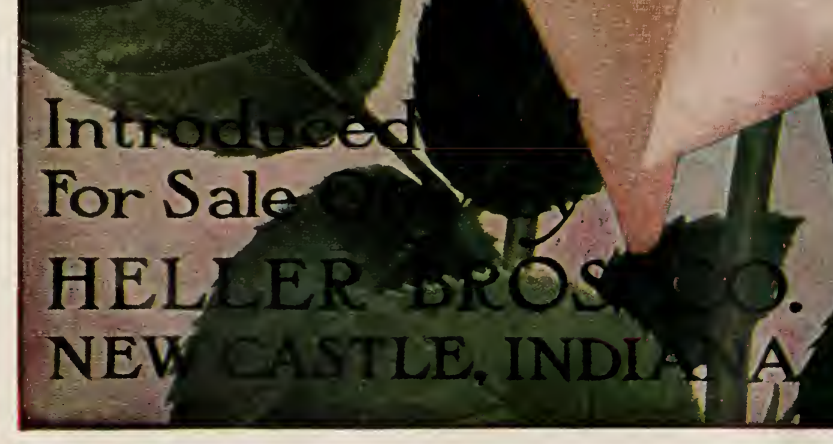

